\title{
Kersantites and associated intrusives from the type locality (Kersanton), Variscan Belt of Western Armorica (France)
}

\author{
Caroff M. ${ }^{1,}{ }^{*}$, Barrat Jean-Alix ${ }^{2}$, Le Gall B. ${ }^{1}$
}

1 UMR/CNRS n6538 "Laboratoire Géosciences Océan », Université de Brest, Institut Universitaire Européen de la Mer (IUEM), Place Nicolas Copernic, 29280 Plouzané, France

${ }^{2}$ CNRS, UMR/CNRS 6539 « Laboratoire des Sciences de l'Environnement Marin », LIA BeBEST, Université de Brest, Institut Universitaire Européen de la Mer (IUEM), Place Nicolas Copernic, 29280 Plouzané, France

*Corresponding author : M. Caroff, email address : caroff@univ-brest.fr

\begin{abstract}
:
Kersantite is the international designation for hypabyssal lamprophyres essentially made up of dark micas and plagioclase. Kersantites from the type locality (Kersanton hamlet) and the W-Armorican surrounding area are Serpukhovian/Bashkirian in age. They are systematically associated in the field with hypabyssal microgranodiorites, both types being intruded synchronously as syn-compressional magmatic bodies that postdated pre-tectonic Tournaisian/Visean dolerites. The kersantitic amphibole compositions can be used to constrain the crystallization pressures and oxygen fugacities (redox conditions much more oxidizing than the $\mathrm{Ni}-\mathrm{NiO}$ buffer). The oscillatory zoning observed in clinopyroxene phenocysts is consistent with a magma chamber repeatedly refilled by mafic liquid. The melting source of the W-Armorican kersantites corresponded to a lithospheric mantle located in the spinel-garnet transition zone (75-85 km depth), highly metasomatized by fluids probably released by a subducted sediment-bearing slab. Microgranodiorites could result from intimate mixing between mantle- and crust-derived magmas, with cordierite as possibly melting phase. The emplacement of dolerites with anorogenic geochemical signature prior to kersantites/microgranodiorites implies upwelling of the asthenospheric mantle up to a relatively high level, probably as the result of an extension induced by either roll back of the subducted lithospheric slab or delamination of the overriding plate. The heat input associated to the long-lasted asthenosphere rise could have favored (1) the formation of early dolerites between 347 and $330 \mathrm{Ma}$; and then, (2) the genesis of syn-compressional kersantites and microgranodiorites between 330 and $310 \mathrm{Ma}$, once the overlying lithospheric mantle was metasomatized by crust-derived fluids. This magmatic sequence marked the beginning of the Avalonia-Armorica collision, just prior to the main Variscan compressional event in this zone at c. $315 \mathrm{Ma}$.
\end{abstract}




\section{Graphical abstract}

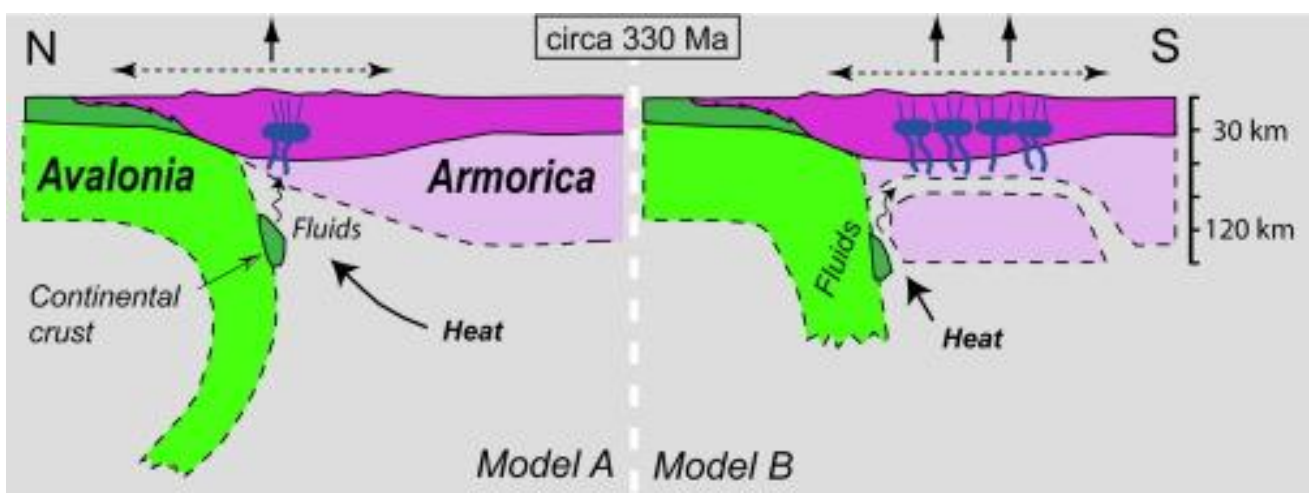

\section{Highlights}

The W-Armorican kersantites were emplaced in a syn-compressional Variscan setting. Hypabyssal kersantites (330-310 Ma) postdated pre-tectonic dolerits (347-330 Ma). Kersantites are interwoven with mantle/crust-derived microgranodiorites. Kersantite mantle source was a c. $80 \mathrm{~km}$-deep metasomatized lithosphere. Extension due to lithosphere roll back or delamination caused asthenosphere uprise.

Keywords : Kersantite, Lamprophyre, Metasomatism, Variscan belt, Armorica 


\section{Introduction}

Lamprophyres are hypabyssal glistening high-K igneous mafic rocks reputed to derive from highly metasomatized upper mantle sources in continental environment (Owen, 2008; Dijkstra and Hatch, 2018; Soder and Romer, 2018; Krmíček et al., 2020). They are generally emplaced at a late- or post-collision stage (Awdankiewicz, 2007; Owen, 2008; Caroff et al., 2015; Tappe et al., 2016; Dijkstra and Hatch, 2018; Errandonea-Martin et al., 2018; Soder and Romer, 2018; Krmíček et al., 2020; Orejana et al., 2020). Krmíček et al. (2020) have also evidenced Variscan syn-orogenic lamprophyres in the Bohemian Massif. Alternatively, lamprophyres can derive from Andean-type subduction-modified subcontinental lithospheric mantle in an extensional regime (e.g., Orozco-Garza et al., 2013; Ma et al., 2014).

Kersantite is a petrographic term stemmed from the name of the hamlet Kersanton (Loperhet, France), and conventionally used as the international designation for intrusive lamprophyres essentially made up of dark micas and plagioclase (Le Bas, 2007). The kersantites from the type locality and its surrounding area were emplaced in the western part of the Armorican Variscan belt between the late Mississippian and the early Pennsylvanian. Though forming, with their associated intrusives, one of the densest hypabyssal swarm in the Armorican Variscides, they have not benefited from recent studies since the pioneer works of Velde (1968, 1971), Thonon (1973, 1975), and Turpin et al. (1988).

The W-Armorican kersantites investigated in this study are systematically associated in the field with hypabyssal microgranodiorites. Both were emplaced after intra-basinal (anorogenic) dolerites during the onset of compression (Rolet and Thonon, 1979; this study). These intrusions deserve to be fully investigated in terms of petrology and geochemistry, with the aim to assess, among other issues, the source composition and melting depth of the 
corresponding syn-orogenic magmas. All together, these data provide new insight into the early period of the Variscan orogeny in Western Europe.

\section{The lamprophyre classification debate}

The term "lamprophyre" has been first proposed by Gümbel (1874) for "dark-coloured dyke and sill rocks distinguished by an abundance of glistening mica flakes" embedded in a feldspar groundmass. In analogy to these, Rosenbusch (1896) added the amphibole-bearing types. At that time, the lamprophyre group comprised four types: kersantite, spessartite, minette and vogesite, depending on the type of feldspar (mainly plagioclase for the first two types; mainly alkali feldspar for the other two) accompanying chiefly dark micas (kersantite and minette) or amphibole (spessartite and vogesite); plus a fifth variety, more alkaline and titaniferous: camptonite (Le Bas, 2007). Much later, Rock (1991) identified 22 additional types to constitute a large supergroup, including notably ultramafic and foid-/melitite-bearing rocks. This author classified them into five branches: 1, calc-alkaline lamprophyres (the Rosenbusch's lamprophyric types, less camptonite); 2, alkaline lamprophyres (including camptonite); 3, ultramafic lamprophyres; 4, kimberlites; and 5, lamproites. Mitchell (1994) argued that the term "lamprophyre" in the Rock's (1991) sense has no genetic significance. In his view, this term merely refers to a large polygenetic group of magmatic rocks, which have formed by crystallization under volatile-rich conditions. In 2002, the IUGS Subcommission on the Systematics of Igneous Rocks proposed to return to Rosenbusch's original five types (Le Maitre et al., 2002), even though Tappe et al. (2005) pleaded for the reintroduction of the ultramafic varieties into the IUGS lamprophyre classification.

Nowadays, many authors prefer to use the Rock's (1991) polygenetic classification rather than follow the IUGS recommendations (e.g., Dijkstra and Hatch, 2018; Errandonea- 
Martin et al., 2018; Soder and Romer, 2018). In the present work, however, kersantites will simply be considered as "lamprophyres", following Le Maitre et al. (2002), instead of "calcalkaline lamprophyres” (Rock, 1991).

\section{Geology}

\subsection{Regional context}

The study area is located in the Brest Bay, in the Central-Armorican Domain (CAD) at the western extremity of the Armorican peninsula, which is part of the pre-Variscan Armorica microplate (Fig. 1). The kersantites and the microgranodiorites under study are locally associated in the field with dolerites, the geochemical characteristics of which (Supplementary Data, Table S1) are closely similar to those of the Tournaisian/Visean Armorican mafic rocks shown in Fig. 2a, i.e.: (i) the $347 \pm 4$ Ma-old (U/Pb zircon) SaintJean-du-Doigt gabbro, located at the limit between the Léon and the North-Armorican Domains (Caroff et al., 2011; Barboni and Bussi, 2013); (ii) the anorogenic transitional basalts associated with Tournaisian/Visean fault-bounded volcano-sedimentary basins in the CAD (Caroff et al., 1996) and Léon Domain (Ouessant: $336 \pm 2 \mathrm{Ma}, \mathrm{U} / \mathrm{Pb}$ zircon; Caroff et al., 2016, 2020); and (iii) the 340-330 Ma-old dyke network in the North-Armorican Domain (NAD) (Lahaye et al., 1995).

Kersantites and microgranodiorites are hosted by Paleozoic metasedimentary formations, generally Devonian (post-Lochkovian) in age (Fig. 2b, c), in the form of sills or dykes. They all belong to a common and multi-stage magmatic event. The largest magmatic body is the $1.5 \mathrm{~km}$-long Île Longue laccolith (Fig. 2b, c). The most recent metasedimentary formation crosscut by this hypabyssal network is the Pont-de-Buis Formation in the 
Châteaulin basin (Fig. 2b), assigned by Doubinger and Pelhate (1976) to the late Visean / early Serpukhovian (c. 332-328 Ma) through miospore identifications. The spatially related dolerite intrusions (Fig. 2c), because of their pre-tectonic origin, are beyond the scope of the present study. Only a few new analyses will be included in some diagrams, for comparative purposes.

\subsection{Structural attributes, timing relationships and other field observations}

The strained Paleozoic host-rocks of the W-Armorican hypabyssal network recorded three types of ductile deformation during the Variscan compression at 320-305 Ma (Marcoux et al., 2009; Schulz, 2013). These are: (i) early syn-cleavage folds, responsible to the regional syncline structure, which are overprinted by (ii) a second generation of folds, all being disrupted by (iii) a dense network of shallowly-dipping shear zones.

The syntectonic origin of the W-Armorican kersantites/microgranodiorites, and thus their emplacement before $c .310 \mathrm{Ma}$ (see Discussion below), is argued from the following evidence. A small number of early intrusions are involved into either folds (Kerdréolet section in Fig. 3a) or shear zones (Kerascoët section in Fig. 3e). On the Larmor section in Fig. 3b, a kersantite intrusion is injected along a minor thrust that cuts a $1^{\text {st }}$-phase fold limb. The existence of shear surfaces cutting through a kersantite apophyse on the upper edge of the intrusion (not drawn) excludes a post-thrust emplacement. The Caro section in Fig. 3c shows a microgranodioritic sill, a few decimeters in thickness, rooting into a vertical dyke, which follows part of a flat-lying shear structure. Small-scale folding of the magmatic layering in the sill (not drawn) is indicative of its injection at a late stage of shearing, prior to the complete crystallization of magma. In Fig. 3d, the deflected trace of the schistosity planes in the 
metasedimentary wall-rocks hosting a shallowly-dipping kersantite sill results from shearing that postdated the magmatic intrusion.

A kersantitic sill intruded in Upper Devonian schist host-rocks in the Kerascoët site, L'Hôpital Camfrout (Fig. 2c), displays both magmatic and tectonic syn-emplacement features. The former ones correspond to vertical columnar joints and vesicle clusters (Fig. 3e-g). These latter are 5-20 cm-long aggregate of bubbles $<0.3 \mathrm{~cm}$ in diameter (Fig. $3 \mathrm{~g}, \mathrm{~h}$ ). They correspond to degassing structures, perhaps in relation with water filling the wall-rock pores (e.g., Caroff et al., 2000). Tectonic structures are represented by a platy joint pattern expressed by closely spaced fractures, typically $2-5 \mathrm{~cm}$ apart and parallel to the shallowlydipping sill base (Fig. 3e, f). They result from syn-emplacement shearing, also expressed by a folded schist band underlying the sill (Fig 3g).

The Le Roz quarry in Logonna-Daoulas (Fig. 2c) exposes a remarkable facies of intrusive Q-phyric microgranodiorite. The rock exhibits concentric iron hydroxide shadows, which result from meteoric water circulation through the joint network (Fig. $3 \mathrm{i}$ inset). This stone, called "Le Roz Stone", has been traditionally used, together with kersantite, for the construction of several historical and religious monuments in Brittany (Fig. 3j).

\section{Petrology and mineralogy}

Among the 64 samples collected for this study, 61 representative samples were petrographically studied by using thin sections, nine samples were analyzed by electron microprobe, 50 for major and trace elements, 31 for ${ }^{87} \mathrm{Sr} /{ }^{86} \mathrm{Sr}$ and 35 samples for ${ }^{143} \mathrm{Nd} /{ }^{144} \mathrm{Nd}$ (Supplementary Data, Table S1). The Q-micromonzonite and microgranodiorites have been classified by using the Streckeisen's (1976) QAP diagram with normative compositions (not shown). The Île Longue intrusion has the texture and composition of a Q-phyric 
micromonzogranite, but, as the corresponding samples plot very close to the granodioritic field, it will not be distinguished from the microgranodiorites. The analytical methods are presented as Supplementary Data.

\subsection{Textural notes}

Some sills/dykes are particularly rich in quartzite and/or diorite xenoliths (e.g., RB-29 area, Fig. 2b; Rostiviec harbor, Loperhet, Fig. 2c), sometimes surrounded by an amphibole/chlorite reaction rim (Velde, 1971).

Fresh kersantites appear as dark-gray rocks and the altered samples are ocher-yellow colored. Their textures range from fine grained (groundmass average length $<0.3 \mathrm{~mm}$ ) to moderately coarse grained (groundmass average length from $0.7 \mathrm{~mm}$ to $1.3 \mathrm{~mm}$ ). Some samples are porphyritic (Supplementary Data, Table S1 and Fig. S1a, b). Kersantites are predominantly made up of plagioclase (between 30 and 45 vol.\%), from labradorite to oligoclase in composition, and of dark micas (between 25 and 40 vol.\%). All rocks contain carbonates and secondary quartz ( $<10 \mathrm{vol} . \%$ in both cases). Groundmass can also comprise green amphibole (RB-43, L'Hôpital Camfrout, Table 1), K-feldspar, Fe-Ti oxides, apatite, and allanite (Velde, 1971). Monazite has been identified in one sample (RB-11).

The most prevalent phenocrysts are dark micas (> $2 \mathrm{~mm}$ in length). Some fresh crystals of amphibole or clinopyroxene (never both together) can be observed as sparse phenocrysts (RB-41, Supplementary Data, Table S1 and Fig. S1a, b, and RB-33, Table 1, respectively). Altered euhedral spinel-bearing olivine phenocrysts are not exceptional. Olivine is systematically altered into chlorite (in the central part), quartz, montmorillonite, talc, calcite, spinelle, and/or prehnite (at the periphery, if any). According to Velde (1968), these olivine transformations would occur in the T-range $400-500{ }^{\circ} \mathrm{C}$. 
Dark micas can be entirely transformed into chlorite, making the rocks much lighter (light-gray kersantites, Supplementary Data, Table S1). Such a hydrothermal alteration affects all the outcrops in some particular areas (especially in L'Hôpital Camfrout and LogonnaDaoulas, Fig. 2c). The other common secondary phases are quartz, carbonates, clay minerals, sericite, and zoisite.

The Q-micromonzonite RB-12b is a moderately coarse-grained, c. $20 \mathrm{~cm}$-thick, mesocratic segregation pod sampled in the kersantite RB-12a (Rhun Vras, L'Hôpital Camfrout, Supplementary Data, Table S1). In the central part of the segregation structure, the texture tends to become pegmatoidic (elongate micas, up to a few centimeters in length). Its contains plagioclase (andesine-oligoclase), largely predominant (> 60 vol.\%), K-feldspar, chloritized dark micas, quartz, Fe-Ti oxides, apatite and secondary calcite.

Microgranodiorites (light-gray when fresh, ocher or white with alteration) are aphanitic or quartz-phyric fine-grained leucocratic rocks. They are made up of oligoclase, generally albitized or damouritized, quartz (sometimes secondary), K-feldspar, chloritized biotite and muscovite (Supplementary Data, Fig. S1c, d).

\subsection{Amphibole and clinopyroxene}

Amphibole occurs in the W-Armorican kersantites as either brown euhedral phenocrysts (RB-41, Supplementary Data, Fig. S1a, b) or green microcrysts (RB-43), not in sufficient quantities for the rocks to be considered as spessartites. Composition of the RB-41 phenocrysts ranges from magnesiohastingsite to tschermakite, and the RB-43 microcrysts have a composition of hastingsite, magnesiohornblende or tschermakite (Supplementary Data, Table S2; Fig. 4a). 
Clinopyroxene phenocrysts can be either partially (RB 7a, Hanvec, Fig. 2c) or completely (RB 5b, Le Faou, Fig. 2c) altered by carbonates, chlorite and quartz. No clinopyroxene microcryst has been identified in the groundmasses. The clinopyroxene phenocrysts are euhedral and have a relatively homogeneous augite/diopside composition (Supplementary Data, Table S3; Fig. 4b), like for lamprophyres from other regions (Rock, 1984; Awdankiewicz, 2007). Their chemical complexity is revealed via the micro-chemical imaging performed on a 2.8 mm-long monomineralic glomerocryst in the sample RB-33 (Fig. 5). The imaged aggregate is made up of six clinopyroxene phenocrysts, in inclusions or interpenetrations. Compositional zoning patterns vary according to elements. Some major elements such as $\mathrm{Ca}$ and $\mathrm{Mg}$ appear relatively homogeneous, whereas other ones $(\mathrm{Al}, \mathrm{Ti}$, and, to a lesser extent, $\mathrm{Fe}$ ) reveal a fine but net oscillatory zoning (between 10 and $60 \mathrm{~mm}$ in width, Fig. 5). The compositional variations between the oscillatory bands in the zoned mantles are shown in Supplementary Data (Table S3).

\subsection{Biotite and phlogopite}

Dark micas in the W-Armorican kersantites consist of biotite and phlogopite, almost in equal proportion (Supplementary Data, Table S4; Fig. 4c), as similarly observed for lamprophyres elsewhere (e.g., Rock, 1984; Awdankiewicz, 2007). They occur both as phenocrysts and in the groundmasses, and they are often completely or partly (at edges) altered by rutile-bearing pale chlorite (Velde, 1971). Although dark micas are in general normally zoned (rims enriched in $\mathrm{FeO}$ and depleted in $\mathrm{K}_{2} \mathrm{O}$ with respect to cores: Supplementary Data, Table S4), biotite and phlogopite compositions are relatively equally distributed between cores and rims in phenocrysts as well as in groundmasses (Fig. 4c). 


\subsection{Carbonates and chlorite}

Kersantite carbonates have a composition of calcite and, more rarely, of ankerite, like the Variscan lamprophyres from the West Sudetes Domain of the Saxo-Thuringian Zone in the Bohemian Massif (Awdankiewicz, 2007). The distinction of primary from secondary carbonates is not easy without $\mathrm{C}-\mathrm{O}$ isotope analyses. The carbonate pseudomorphs and the calcite filling the fractures / vugs represent clearly alteration products. However, semiquantitative electron microprobe analyses (detection limits and errors in Supplementary Data) reveal significant $\mathrm{Sr}$ and $\mathrm{Ce}$ high concentrations in calcites present in the groundmass of samples RB-9b, -41 and -47: $554<\mathrm{Sr}<1473$ ppm; $\mathrm{Ce}=2353$ ppm (only one significant analysis in RB-47). Although not conclusive, these high $\mathrm{Sr}$ and Ce concentrations are rather consistent with a primary (magmatic or late-magmatic) origin for these crystals, as already proposed by Seifert (2008) for kersantites and by Huang et al. (2002) for ocelli-bearing minettes.

Chlorites are chemically homogeneous. They plot in the diabantite field in the Hey's (1954) diagram (Fig. 4d). In the Sudetes, such a diabantite composition is characteristic of kersantites and minettes, whereas vogesites and spessartites contain mainly pycnochlorite (Awdankiewicz, 2007).

\section{Geochemistry}

\subsection{Alteration}

The studied kersantite samples are reasonably fresh, in spite of their high LOI values (from 4.12 to 10.71 wt.\%, Supplementary Data, Table S1), a common feature of kersantites 
(e.g., Awdankiewicz, 2007; Krmíček et al., 2020), and the occurrence of the abovementioned secondary minerals. More numerous alteration phases are present in the microgranodiorites (see text above), except in the Île Longue fresher samples LC-IL-1 and -2 (Supplementary Data, Table S1). Comparing the major and trace element composition of the two latter samples with those of the other microgranodiorites reveals that a moderate alteration has no significant geochemical impact in this group.

\subsection{Major elements}

The W-Armorican kersantites plot in the middle of the total alkali vs. silica (TAS) diagram of Le Bas and Streckeisen (1991), consistently with the Rock’s (1987) lamprophyre data (Fig. 6a). High-Mg (MgO > 9 wt.\%) kersantites are distinguished in this and following diagrams. The Q-micromonzonite RB-12b has a trachydacitic composition and the microgranodiorites plot in the rhyolitic field (Fig. 6a). Among the European Variscan kersantites plotted for comparison, only those from the Black Forest display more evolved compositions (Soder and Romer, 2018). In the $\mathrm{CaO}-\mathrm{SiO}_{2} / 10-4 \mathrm{TiO}_{2}$ diagram of Fig. $6 \mathrm{~b}$, all the European Variscan kersantites plot in the lamprophyre field of Rock (1987). The shoshonitic affinity of the W-Armorican kersantites is evidenced by the $\mathrm{K}_{2} \mathrm{O}$ vs. $\mathrm{Na}_{2} \mathrm{O}$ classification diagram of Fig. 6c, after Foley et al. (1987). In the classic A/CNK vs. A/NK Shand's diagram of Fig. 6d (Maniar and Piccoli, 1989), the European Variscan kersantites plot in the metaluminous field contrary to the W-Armorican microgranodiorites, which are peraluminous. Note that the Q-micromonzonite RB-12b plots in the metaluminous field close to the peralkaline limit.

The variation diagrams of Fig. 7 show that $\mathrm{MgO}$ and $\mathrm{Fe}_{2} \mathrm{O}_{3} *$ are negatively correlated with $\mathrm{SiO}_{2}$ (Fig. 7a, b), whereas $\mathrm{Na}_{2} \mathrm{O}$ shows a positive correlation with $\mathrm{SiO}_{2}$ (Fig. 7c). The 
clinopyroxene- and amphibole-bearing kersantites do not plot away from the main trend. The Q-micromonzonite RB-12b has a composition in major elements intermediate between that of the kersantites and microgranodiorites (Fig. 7).

\subsection{Trace elements and isotopes}

In the spider diagrams normalized to primitive mantle of Fig. 8, the W-Armorican kersantites and Q-micromonzonite (Fig. 8a) display patterns comparable to those of the other European Variscan kersantites (Fig. 8b): negative slope, negative anomalies in $\mathrm{Rb}, \mathrm{Ba}, \mathrm{Nb}, \mathrm{Ta}$ and $\mathrm{Ti}$, and, for a few samples, a slight positive anomaly in $\mathrm{Pb}$. Note that the Black Forest kersantites show a more pronounced Pb peak (Fig. 8b; Soder and Romer, 2018). The GLOSS (GLObal Subducted Sediment: Plank and Langmuir, 1998) composition, also reported for comparison (Fig. 8a), traces out a pattern which is not very different from the kersantite curves, except for lower Th, U and LREE (light rare earth element) and slightly higher HREE (heavy REE). The older W-Armorican dolerites differ radically, with trace element compositions very close to those of Armorican Tournaisian/Visean anorogenic mafic rocks (Lahaye et al., 1995; Caroff et al., 1996, 2011, 2016). Although displaying more scattered patterns, the microgranodiorite do not part away from kersantites (Fig. 8c). The main differences are: negative anomalies in $\mathrm{Ba}$, higher values in $\mathrm{Nb}$ and $\mathrm{Ta}$, more marked positive $\mathrm{Pb}$ peak and lower values in HREE.

Strontium and neodymium isotopic compositions (Table 2) are plotted in Fig. 9 for the W-Armorican kersantites and associated intrusives together with kersantites from the Bohemian Massif, the N-Odenwald, the Vosges mountains, the Black Forest, and the SWEngland region (Fig. 9). The trend defined by the W-Armorican kersantites extends on the right side of the mantle array, as similarly displayed by kersantites from the N-Odenwald and 
the Vosges mountains. The Black Forest field locates at the extremity of this trend toward lower initial $\varepsilon_{\mathrm{Nd}}$ values and higher initial ${ }^{87} \mathrm{Sr} /{ }^{86} \mathrm{Sr}$ values. Finally, the highest initial $\varepsilon_{\mathrm{Nd}}$ values correspond to those of the Bohemian kersantites, on both sides of the CHUR line.

Microgranodiorites have isotope compositions comparable to the kersantite ones. Note that the Bohemian orogenic lamprophyres have negative initial $\varepsilon_{N d}$ values like the $\mathrm{W}$-Armorican kersantites, whereas the Bohemian post-orogenic lamprophyres have initial $\varepsilon_{\mathrm{Nd}}>0$ (Fig. 9 inset), such as the Armorican Tournaisian/Visean anorogenic mafic rocks (Fig. 9).

\section{Discussion}

\subsection{Physicochemical properties of the kersantitic melt}

As the classical empirical methods to estimate pressure of crystallization of calcic amphiboles from their $\mathrm{Al}^{\mathrm{T}}$ content are only useful for near-solidus granitoid plutons (e.g., Hollister et al., 1987; Pál-Molnár et al., 2015), we apply here the empirical method of Ridolfi and Renzulli (2012), based on the whole major element composition of the Ca-amphiboles and valid for calc-alkaline and alkaline magmas up to $1,130{ }^{\circ} \mathrm{C} / 2.2 \mathrm{GPa}$. This geobarometer is used here to estimate the crystallization pressure of the brown phenocrysts present in samples RB-41 and the green microcrysts of RB-43. In our calculations (presented in Supplementary Data, Table S2), we have only considered the core compositions. Two ranges of pressures have been estimated by this method (with an uncertainty of $11.5 \%$ ), whatever the amphibole composition is: 701-807 MPa for RB-41 and 205-308 MPa for RB-43 (Fig. 4a). The first range of pressures could be indicative of the reservoir depth (between 25.9 and 29.9 $\mathrm{km}$, for a crustal density of $2.8 \times 10^{3} \mathrm{~kg} / \mathrm{m}^{3}$ ), whereas the second range of values, 
corresponding to the RB-43 amphibole microcrysts, would provide information on the depth of dyke/sill emplacement (between 7.6 and $11.4 \mathrm{~km}$ ).

Since the validity of the pressure estimates of Ridolfi and Renzulli (2012) was questioned by Erdmann et al. (2014), we have calculated crystallization temperatures of RB33 clinopyroxene phenocrysts by introducing in the T-dependent geobarometer of Nimis (1999) (for $\mathrm{H}_{2} \mathrm{O}$-rich melts) the pressures estimated from the RB-41 amphibole phenocrysts. Note that RB-33 and RB-41 have equivalent mg\# (Supplementary Data, Table S1). The results (mean values) range from $1030{ }^{\circ} \mathrm{C}$ for $\mathrm{P}=807 \mathrm{MPa}$ to $1051{ }^{\circ} \mathrm{C}$ for $\mathrm{P}=701 \mathrm{MPa}$ (Supplementary Data, Table S3). These T values, realistic for lamprophyric rocks (e.g., Ubide et al., 2014), can be viewed as an indirect validation of the geobarometer of Ridolfi and Renzulli (2012) for the studied kersantites.

Once pressure was calculated, the empirical method of Ridolfi and Renzulli (2012) has been used to obtain relative oxygen fugacity $\left(\mathrm{fO}_{2}\right)$ values, i.e. $\Delta \mathrm{NNO}=\operatorname{logf\mathrm {O}_{2}}-\operatorname{logf\mathrm {O}_{2}}$ at the $\mathrm{Ni}-\mathrm{NiO}$ buffer, expressed as $\log$ units $( \pm 0.37 \log$ units). The results indicate that the kersantitic amphiboles crystallized at very high oxygen fugacities, that is, at redox conditions much more oxidizing than the NNO buffer: $\Delta \mathrm{NNO}>3.75 \log$ units for RB-41 and $0.89<$ $\Delta \mathrm{NNO}<3.25 \log$ units for RB-43.

\subsection{Differentiation and reservoir mechanisms}

The major element variations in kersantites and microgranodiorites shown in Fig. 7 could be explained in terms of fractionation of biotite/phlogopite, amphibole, clinopyroxene \pm Fe-Ti oxides in a closed-system magma chamber if (i) the isotopic ratios were constant and (ii) the variation of the incompatible trace element ratios was consistent with mineral separation. But this is not the case, especially between the two main petrographic types (Figs 
8,9 , and following). Thus, fractional crystallization ( \pm crustal contamination) must be considered as a subordinate mechanism to explain the rock composition. However, the passage from the kersantitic sample RB-12a to its leucocratic segregation pod RB-12b, Qmonzonitic in composition, could be explained through in situ differentiation (Fig. 7). Such pegmatitic-textured segregation structures, common in mafic flows and intrusions (see Caroff et al., 2000, for a review), can result from various mechanisms coeval with the emplacement, such as compaction (Philpotts et al., 1996) or vapor-differentiation (Caroff et al., 2000). The formation of the RB-12 segregation pod is consistent with main fractionation of biotite/phlogopite (Fig. 7b, c).

Major element variations in oscillatory zoned clinopyroxenes are generally explained by either intrinsic mechanisms linking crystal growth to local phenomena, involving coupling between growth rate and solute diffusion through the crystal-melt interface, or extrinsic mechanisms involving chemical changes in the bulk magmatic system (e.g., crystal settling, convection, or reservoir replenishment) (Shore and Fowler, 1996). The intrinsic mechanisms are thought to produce fine banding $(<15 \mu \mathrm{m}$ in plagioclase $)$ with low compositional amplitude (Ginibre et al., 2002). The characteristics of the mantle zoning in the RB-33 clinopyroxene glomerocryst (band width ranging from 10 to $60 \mu \mathrm{m}$ and high $\mathrm{Al}$ and $\mathrm{Ti}$ variations) seem rather consistent with an extrinsic mechanism. To explain the formation of oscillatory zoning in the Stromboli clinopyroxene megacrysts, which display features comparable, for the same major elements, to those evidenced in the RB-33 glomerocryst, Ubide et al. (2019) proposed a refilling-type mechanism during which each replenishment event would be followed by minor magma fractionation. In their model, the clinopyroxenes would have crystallized at the margin of a reservoir remaining stable during the core growth and repeatedly replenished during the mantle crystallization. We believe that such an open- 
system model can suitably account for the oscillatory zoning observed in the RB-33 clinopyroxenes.

\subsection{Source discussion}

\subsubsection{Kersantites}

The W-Armorican kersantites are characterized by low $\mathrm{SiO}_{2}$ (45-56 wt.\%, Fig. 6a), high $\mathrm{MgO}$ (5.5-15 wt.\%, Fig. 7a) and high Ni (53-371 ppm, Supplementary Data, Table S1) values, which suggest that they are derived from a peridotitic mantle source. Their isotopic compositions, plotting on the right side of the mantle array in the initial $\varepsilon_{\mathrm{Nd}} \mathrm{vs}$. initial ${ }^{87} \mathrm{Sr} /{ }^{86} \mathrm{Sr}$ diagram (Fig. 9), are consistent with the involvement of recycled sediment with relatively uniform isotopic signal in the melting source (e.g., Krmíček et al., 2016; Dijkstra and Hatch, 2018; Krmíček et al., 2020).

The Dy/Yb vs. $\log \left(\mathrm{K}_{2} \mathrm{O} / \mathrm{Na}_{2} \mathrm{O}\right)$ diagram of Fig. 10a suggests that kersantitic primary liquids result from partial melting of a mantle source at a relatively constant depth, but with variable degrees. The $\mathrm{Rb} / \mathrm{Sr}$ vs. $\mathrm{Ba} / \mathrm{Rb}$ diagram of Fig. $10 \mathrm{~b}$ can be used to discriminate between a phlogopite- vs. an amphibole-bearing source. Contrary to the kersantites from Sierra Bermeja and the Black Forest, clearly derived from a phlogopite-bearing source, the W-Armorican kersantites distribute between both trends (Fig. 10b), suggesting the probable presence of both minerals in the melting source region. The Dy/Yb vs. K/(1000Yb) plot (Fig. 10c) can be used to constrain the mineralogical composition of the melting source, in particular to discriminate between the spinel and the garnet stability fields. Melts produced in the garnet stability field generally have $\mathrm{Dy} / \mathrm{Yb}$ ratios $>2.5$, whereas melting in the spinel stability field gives lower Dy/Yb ratios (<1.5) (Duggen et al., 2005; Ma et al., 2014). The WArmorican kersantites have $\mathrm{Dy} / \mathrm{Yb}$ ratios ranging from 1.9 to 2.9 , with a majority of samples 
between 2 and 2.5 (Fig. 10c). This implies that the partial melting took place in the spinelgarnet transition zone, assumed to be located between 75 and $85 \mathrm{~km}$ depth (Robinson and Wood, 1998; Ma et al., 2014), with phlogopite \pm amphibole as accessory hydroxyl minerals.

The crust/sediment participation to the kersantite formation is especially well documented through the diagrams in Fig. 11. In the $\log (\mathrm{Ce} / \mathrm{Pb})$ vs. $\log (\mathrm{Ce})$ in Fig. 11a, the kersantites form a well-defined trend from the OIB field toward the average continental crust and pelagic sediment fields. This linear evolution is comparable to that of the other European Variscan kersantites. The fact that the $\mathrm{Ce} / \mathrm{Pb}$ ratio is not correlated with any differentiation parameter, such as $\mathrm{MgO}, \mathrm{SiO}_{2}$ contents or $\mathrm{mg \#} \mathrm{index,} \mathrm{precludes} \mathrm{any} \mathrm{significant} \mathrm{assimilation}$ coupled with fractional crystallization (AFC) (De Paolo, 1981). In the $\log (\mathrm{Hf} / \mathrm{Sm})_{\mathrm{N}}$ vs. $\log (\mathrm{Ta} / \mathrm{La})_{\mathrm{N}}$ diagram of Fig. $11 \mathrm{~b}$, another trend is obvious, extending along the fluid-related subduction metasomatism field. The other European Variscan kersantites show comparable features. Note that in the Fig. 11 diagrams, the Brest Bay dolerites plot between the MORB and the OIB fields, making them transitional mafic products.

The melting source of the W-Armorican kersantites corresponded to a 75-85 km-deep mantle region, located in the spinel-garnet transition zone. The Sr-Nd isotope and trace element diagrams are rather consistent with a lithospheric mantle reservoir (Krmíček et al., 2016; 2020), modified by contributions from the subducting plate and its cover through metasomatism.

\subsubsection{Microgranodiorites}

The W-Armorican microgranodioritic hypabyssal network is inextricably interwoven with the kersantitic one (Fig. 2b, c), hence suggesting that they are both synchronous and genetically related. Despite a certain resemblance between their respective trace element 
patterns (Fig. 8c), and their similar range of initial $\varepsilon_{\mathrm{Nd}}$ (Fig. 9), their trace element ratios are too contrasted to be explained through a simple fractionation mechanism (Figs 8, 12, and 13).

Lamprophyres worldwide are commonly accompanied by felsic intrusives, generally interpreted as the result of hybridization of mantle-related (lamprophyric) melt by crustrelated felsic melts (e.g., Krmíček et al., 2020). In the same vein, post-orogenic leucominettes have been interpreted by Prelević et al. (2004) as the result of hybridization between crustalderived dacitic magmas and mantle-derived lamproitic melts. In the present case, there are also several arguments in favor of a crustal component in the genesis of the microgranodiorites.

$\mathrm{The} \mathrm{Nb} / \mathrm{Ta}$ vs. $\mathrm{Nb}$ diagram of Fig. 12 is classically used to support fractionation of $\mathrm{Nb}$ and Ta by mica during continental partial melting (Stepanov and Hermann, 2013). Indeed, leucosomes resulting from incipient partial melting of crustal rocks are reputed to have subchondritic $\mathrm{Nb} / \mathrm{Ta}$ ratios, contrary to biotite-rich restites, characterized by high $\mathrm{Nb} / \mathrm{Ta}$ values (Fig. 12). Microgranodiorites have $\mathrm{Nb} / \mathrm{Ta}$ ratios comparable to those of leucosomes, while differentiation is supposed to increase the $\mathrm{Nb}$ concentrations at constant $\mathrm{Nb} / \mathrm{Ta}$ (Fig. 12).

The Fig. 13 diagrams show the behavior of $\mathrm{Cs}, \mathrm{Be}$ and $\mathrm{Ga}$ with respect to $\mathrm{Yb}$. $\mathrm{Yb} / \mathrm{Cs}$, $\mathrm{Yb} / \mathrm{Be}$, and $\mathrm{Yb} / \mathrm{Ga}$ vs. denominators display decreasing hyperbolic curves for kersantites and microgranodiorites. Both types fall into the same hyperbole, but the microgranodiorites are more detached for Be and Ga (Fig. 13b, c) than for Cs (Fig. 13a). Cordierite is one of the rare phases with which these three elements are highly compatible (references in Fig. 13). It results that the cordierite/melt distribution coefficients follow this sequence: $\mathrm{Yb}<<\mathrm{Cs}<<\mathrm{Be}<\mathrm{Ga}$. A pressure-temperature diagram for fluid-present conditions during experimental melting of a cordierite-bearing gneiss is shown in Fig. 13b inset (from Koester et al., 2002). For a pressure $>700 \mathrm{MPa}$ and a temperature of $c .900{ }^{\circ} \mathrm{C}$, cordierite entirely 
dissolves into the melt, while biotite remains in the residuum (in agreement with Bea et al., 1994). These data highly suggest that cordierite was a crustal melting phase that has enriched the granodioritic melt in $\mathrm{Be}, \mathrm{Ga}$, and, in a lesser extent, in Cs.

The W-Armorican microgranodiorites are probably of crust/mantle mixed origin: they likely derive from intimate mixing between cordierite-bearing crustal felsic melts and kersantite-type mantle-related melts.

\subsection{Geodynamic significance}

The Armorican Massif is viewed by most authors as a double-suture subduction/collision chain (Matte, 2001; Ballèvre et al., 2009). To the south, the collision was eo-Variscan and occurred in the Upper Devonian (Ballèvre et al., 2009). To the North, south of the Lizard Devonian ophiolite complex (Le Gall, 1990) (Fig. 1), Variscan tectonics resulted in the development of a nappe stack in the Léon Domain (Authemayou et al., 2019). Deformation in the adjoining Central-Armorican Domain (CAD, Fig. 2a) to the south occurred at the same time, in the Pennsylvanian (and not in the Upper Devonian/Early Tournaisian, as suggested by the proponents of the "Breton phase": e.g., Rolet et al., 1994), after the development of Visean fault-bounded volcano-sedimentary basins (present in both the CAD and Léon Domain: Caroff et al., 2020). We do not agree with the hypothesis of an allochtonous origin of the "Léon block", as being thrusted over the CAD and viewed as the eastern prolongation of the Saxo-Thuringian zone (Ballèvre et al., 2009). Instead, many field arguments are in favor of a strict lateral continuity between the Léon Domain (infra-crustal) and CAD (supra-crustal) during the Variscan orogeny (Le Gall et al., 2014; Caroff et al., 2020). After the closure of the Rheic ocean, in Carboniferous times, the Armorica microplate 
was thrusted over the southern margin of the Avalonia microplate (Matte, 2001; Ballèvre et al., 2009; Schulz, 2013; Franke et al., 2017).

The Th-Hf-Nb/2 discrimination diagram of Krmíček et al. (2011) can be used to compare Variscan anorogenic/orogenic mafic rocks from both the Armorican and the Bohemian Massifs (Fig. 14). Geochemical data about the W-Armorican kersantites are not consistent with a melting depth higher than $85 \mathrm{~km}$ (spinel-garnet transition zone, Fig. 10c). The corresponding P/T pattern favors a model with an asthenospheric mantle lying at a higher level than expected in a "normal" continental setting. Such a situation is possible in a convergence context and might result from an extension attributable to the roll back of the subducted lithospheric slab (Model A of Fig. 15a: Duretz et al., 2011; Guillot and Replumaz, 2013). In a comparable situation, Ma et al. (2014) have alternatively proposed the detachment of the deep part of the overriding lithospheric mantle (Model B of Fig. 15b). Such a delamination process could be caused by the negative buoyancy of the mantle lithosphere ( $\mathrm{Li}$ et al., 2016). In both models, the adiabatic rise of the asthenosphere leads to decompression melting. The resulting heat increase may also induce the melting of the overlying lithospheric mantle (Ma et al., 2014). In such views, fragments of buried continental crust are supposed to form suitable reservoirs for fluid release and mantle metasomatism (Fig. 15).

With regards to the Armorica plate setting, such an extensional regime could have first resulted, prior to the kersantite emplacement, in the formation of strike-slip fault-bounded Visean volcano-sedimentary basins in the CAD and Léon Domain (Caroff et al., 1996; 2020). The asthenosphere upwelling and melting could have favored the formation of the Armorican Tournaisian-Visean mafic rocks (347-300 Ma) at that basinal stage. Later on, kersantites originated from partial melting of the overlying lithospheric mantle $(75-85 \mathrm{~km})$ once it had been highly metasomatized by continental crust-released fluids (Fig. 15). This event took place between 330 and $310 \mathrm{Ma}$. The lower limit corresponds to the age of the most recent 
metasedimentary formation crosscut by the W-Armorican kersantite/microgranodiorite hypabyssal network (330 \pm 2 Ma: Doubinger and Pelhate, 1976), whereas the upper limit (310 $\pm 5 \mathrm{Ma}$ ) is bracketed by (1) the metamorphism peak that was reached at $c .315 \mathrm{Ma}$ in the Léon Domain (Schulz, 2013) and (2) the emplacement of late-/post-orogenic Léon granites (304296 Ma: Marcoux, 2009; Caroff et al., 2015) (for the CAD, the granite geochronology is outdated and highly questionable). Such a pre-collisional (347-330 Ma) / syn-collisional (330$310 \mathrm{Ma}$ ) evolution in the Armorican Variscan segment is a mirror image of that observed in the Bohemian Massif from the syn-collisional lamprophyres and associated rocks (340-300 Ma) to the post-collisional ones (300-275 Ma) (Krmíček et al., 2020), in terms of both isotopes (Fig. 9 inset) and trace elements (Fig. 14). This sequence of events marked the beginning of the Avalonia-Armorica collision, well after the eo-Variscan convergence (Middle/Upper Mississippian) between Gondwana and Armorica to the south (Ballèvre et al., 2009).

\section{Concluding remarks}

(1) The kersantite network from the western part of the Armorican Variscides was emplaced between 330 and $310 \mathrm{Ma}$ in a syn-compressional tectonic setting, contrary to most lamprophyres worldwide that commonly postdate deformations.

(2) Geochemical data have been used to constrain a kersantite melting depth of approximately $75-85 \mathrm{~km}$.

(3) Kersantites are spatially and temporarily associated with another lithological type: hypabyssal microgranodiorites. Kersantites resulted from melting of lithospheric mantle metasomatized by fluids issued from a subducted crust/sediment-bearing 
slab, whereas microgranodiorites are the product of mixing between cordieritebearing crustal felsic melts and mantle-related melts.

(4) In our model, the asthenospheric mantle was located at a higher level than expected in a normal continental setting. Such a situation should result from an asthenospheric-scale extension due to either the roll back of the subducted Avalonia lithospheric slab or, alternatively, delamination of the overriding Armorica lithosphere.

(5) The early period of the Variscan orogeny in Armorica is here revised by stating a new sequence of magmatic events. The intrusion of the W-Armorican lithospherederived kersantite/microgranodiorite hypabyssal network (330-310 Ma) postdated the emplacement of the widespread asthenosphere-derived pre-compressional mafic products (347-330 Ma) and took place during the onset of deformation in both the Léon and Central-Armorican Domains (320-305 Ma).

\section{Acknowledgements}

This project was funded by the Armorique Regional Nature Park (PNRA) / Armorique Geopark, Le Faou, and by the Ocean Geosciences Laboratory, IUEM, Brest (France). Field studies were conducted in 2019. The authors are grateful to S. Gravat-Hodan for her field contribution, for her participation to the microprobe sessions and for microphotographs, to C. Caurant for her analytical assistance, as part of their Master's projects at the University of Brest, and to C. Authemayou for fruitful discussion on geodynamics. We thank J.-J. Barreau (Director of PNRA), J. Bourdoulous (Director of natural heritage, PNRA), N. Courant (Armorique Geopark Coordinator, PNRA), J. Langlade (microprobe analyses), C. Liorzou (ICP-AES), B. Guéguen and M.-L. Rouget (HR-ICP-MS), Ph. Nonnotte and K. Quessette (Sr and Nd analyses), P. Tieffenbach (thin sections), and J.-P. Oldra (sample preparation). 
Detailed and constructive comments by Drs L. Krmíček, G. Pe-Piper and D. Prelević helped us a lot to improve the first version of the text. The authors thank Dr. S. Tappe for his editorial handling.

\section{References}

Authemayou, C., Le Gall, B., Caroff, M., Bussien Grosjean, D., 2019. Wrench-related dome formation and subsequent orogenic syntax bending in a hot orogen (Variscan IberoArmorican Arc, the Ouessant Island, France). Tectonics 38.

https://dx.doi.org/10.1029/2018TC005189.

Awdankiewicz, M., 2007. Late Palaeozoic lamprophyres and associated mafic subvolcanic rocks of the Sudetes (SW Poland): petrology, geochemistry and petrogenesis. Geol. Sudetica 39: 11-97.

Babin, C., Darboux, J.R. (coordinators), 1982. Geological map of France, sheet Le Faou (275). BRGM, Orléans, scale 1:50,000.

Ballèvre, M., Bosse, V., Ducassou, C., Pitra, P., 2009. Palaeozoic history of the Armorican Massif: Models for the tectonic evolution of the suture zones. C. R. Geosci. 341, 174201. https://dx.doi.org/10.1016/j.crte.2008.11.009.

Barboni, M., Bussy, F., 2013. Petrogenesis of magmatic albite granites associated to cogenetic A-type granites: Na-rich residual melt extraction from a partially crystallized A-type granite mush. Lithos 177, 328-351.

http://dx.doi.org/10.1016/j.lithos.2013.07.005.

Bea, F., Pereira, M.D., Stroh, A., 1994. Mineral/leucosome trace-element partitioning in a peraluminous migmatite (a laser ablation-ICP-MS study). Chem. Geol. 117, 291-312. https://dx.doi.org/10.1016/0009-2541(94)90133-3. 
Caroff, M., Coint, N., Hallot, E., Hamelin, C., Peucat, J.-J., Charreteur, G., 2011. The maficsilicic layered intrusions of Saint-Jean-du-Doigt (France) and North-Guernsey (Channel Islands), Armorican Massif: Gabbro-diorite layering and mafic cumulate-pegmatoid association. Lithos 125, 675-692. https://dx.doi.org/10.1016/j.lithos.2011.03.019.

Caroff, M., Labry, C., Le Gall, B., Authemayou, C., Bussien Grosjean, D., Guillong, M., 2015. Petrogenesis of late-Variscan high-K alkali-calcic granitoids and calc-alkalic lamprophyres: The Aber-Ildut/North-Ouessant complex, Armorican Massif, France. Lithos 238, 140-155. http://dx.doi.org/10.1016/j.lithos.2015.09.025.

Caroff, M., Le Gall, B., Authemayou, C., 2020. How does a monzogranite turn into a trachydacitic extrusion mantled by basinal volcaniclastics and peperites? The case of South-Ouessant, Armorican Variscides (France). J. Geol. Soc. https://dx.doi.org/10.1144/jgs2020-060.

Caroff, M., Le Gall, B., Authemayou, C., Bussien Grosjean, D., Labry, C., Guillong, M., 2016. Relations between basalts and adakitic-felsic intrusive bodies in a soft-substrate environment: the South Ouessant Visean basin in the Variscan belt, Armorican Massif, France. Can. J. Earth Sci. 53, 441-456. https://dx.doi.org/10.1139/cjes-2015-0230.

Caroff, M., Le Gal, X., Rolet, J., Cotten, J., Thonon, P., 1996. Magmatisme tholeiitique continental en contexte orogénique hercynien : l'exemple du volcanisme viséen de Kerroc'h, Massif armoricain (France). C. R. Acad. Sci. Paris II, 322, 269-275.

Caroff, M., Maury, R.C., Cotten, J., Clement, J.-P., 2000. Segregation structures in vapordifferentiated basaltic flows. Bull. Volcanol. 62, 171-187. https://dx.doi.org/10.1007/s004450000077.

Castaing, C. (coordinator), 1987. Geological map of France, sheet Huelgoat (276). BRGM, Orléans, scale 1:50,000. 
Chauris, L., Plusquellec, Y. (coordinators), 1980. Geological map of France, sheet Brest (274). BRGM, Orléans, scale 1:50,000.

Chauris, L., Plusquellec, Y. (coordinators), 1975. Geological map of France, sheet Douarnenez (309). BRGM, Orléans, scale 1:50,000.

De Paolo, D.J., 1981. Trace element and isotopic effects of combined wallrock assimilation and fractional crystallization. Earth Planet. Sci. Lett. 53, 189-202. https://dx.doi.org/10.1016/0012-821X(81)90153-9.

Dijkstra, A.H., Hatch, C., 2018. Mapping a hidden terrane boundary in the mantle lithosphere with lamprophyres. Nat. Commun. 9:3770. https://dx.doi.org/10.1038/s41467-01806253-7.

Doubinger, J., Pelhate, A., 1976. Nouvelles observations sur l'âge des schistes de Châteaulin (Massif armoricain). C. R. Acad. Sci. Paris 283 (D), 467.

Duggen, S., Hoernle, K., Van den Bogaard, P., Garbe-Schönberg, D., 2005. Post-collisional transition from subduction- to intraplate-type magmatism in the westernmost Mediterranean: evidence for continental-edge delamination of subcontinental lithosphere. J. Petrol. 46, 1155-1201. https://dx.doi.org/10.1093/petrology/egi013.

Duretz, T., Gerya, T.V., May, D.A., 2011. Numerical modelling of spontaneous slab breakoff and subsequent topographic response. Tectonophysics 502, 244-256. https://dx.doi.org/10.1016/j.tecto.2010.05.024.

Erdmann, S., Martel, C., Pichavant, M., Kushnir, A., 2014. Amphibole as an archivist of magmatic crystallization conditions: problems, potential, and implications for inferring magma storage prior to the paroxysmal 2010 eruption of Mount Merapi, Indonesia. Contrib. Mineral. Petrol. 167, 1016. https://doi.org/10.1007/s00410-014-1016-4.

Errandonea-Martin, J., Sarrionandia, F., Carracedo-Sánchez, M., Gil Ibarguchi, J.I., Eguíluz, L., 2018. Petrography and geochemistry of late- to post-Variscan vaugnerite series rocks 
and calc-alkaline lamprophyres within a cordierite-bearing monzogranite (the Sierra Bermaja Pluton, southern Iberian Massif). Geol. Acta 16, 237-255. https://dx.doi.org/10.1344/GeologicaActa2018.16.3.1.

Evensen, J.M., London, D., 2003. Experimental partitioning of Be, Cs, and other trace elements between cordierite and felsic melt, and the chemical signature of S-type granite. Contrib. Mineral. Petrol. 144, 739-757. https://dx.doi.org/10.1007/s00410-0020426-x.

Foley, S.F., Venturelli, G., Green, D.H., Toscani, L., 1987. The ultrapotassic rocks: characteristics, classification and constraints for petrogenetic models. Earth Sci. Rev. 24, 81-124. https://dx.doi.org/10.1016/0012-8252(87)90001-8.

Franke, W., Cocks, L.R.M., Torsvik, T.H., 2017. The Palaezoic Variscan oceans revisited. Gondwana Res. 48, 257-284. http://dx.doi.org/10.1016/j.gr.2017.03.005.

Ginibre, C., Kronz, A., Worner, G., 2002. High-resolution quantitative imaging of plagioclase composition using accumulated backscattered electron images: new constraints on oscillatory zoning. Contrib. Mineral. Petrol. 142, 436-448. https://dx.doi.org/10.1007/s004100100298.

Guillot, S., Replumaz, A., 2013. Importance of continental subductions for the growth of the Tibetan plateau. Bull. Soc. géol. France 184, 199-223. https://dx.doi.org/10.2113/gssgfbull.184.3.199.

Gümbel, K.W., 1874. Die palāolithischen eruptivgesteine des Fichtelgebirges. Franz, Munich. Hey, M. H., 1954. A new review of the chlorites. Mineral. Mag. 30, 277292. https://dx.doi.org/10.1180/minmag.1954.030.224.01.

Hofmann, A.W., 1988. Chemical differentiation of the Earth: the relationship between mantle, continental crust, and oceanic crust. Earth Planet. Sci. Lett. 90, 297-314. https://dx.doi.org/10.1016/0012-821X(88)90132-X. 
Hofmann A.W., Jochum K.P., Seufert M., White W.M., 1986. Nb and Pb in oceanic basalts: new constraints on mantle evolution. Earth Planet. Sci. Lett. 79, 33-45. https://dx.doi.org/10.1016/0012-821X(86)90038-5.

Hollister, L.S., Grissom, G.C., Peters, E.K., Stowell, H.H., Sisson, V.B., 1987. Confirmation of the empirical correlation of $\mathrm{Al}$ in hornblende with pressure of solidification of calcalkaline plutons. Am. Mineral. 72, 231-239.

Huang, Z., Liu, C., Xiao, H., Han, R., Xu, C., Li, W., Zhon, K., 2002. Study on the carbonate ocelli-bearing lamprophyre dykes in the Ailaoshan gold deposit zone, Yunnan Province. Science in China, Series D 45 (6), 494-502.

Koester, E., Pawley, A.R., Fernandes, L.A.D., Porcher, C.C., Soliani Jr. E., 2002.

Experimental melting of cordierite gneiss and the petrogenesis of syntranscurrent peraluminous granites in Southern Brazil. J. Petrol. 43, 1595-1616. https://dx.doi.org/10.1093/petrology/43.8.1595.

Krmíček, L., Cempírek, J., Havlín, A., Přichystal, A., Houzar, S., Krmíčková, M., Gadas, P., 2011. Mineralogy and petrogenesis of Ba-Ti-Zr-rich peralkaline dyke from Šebkovice (Czech Republic): recognition of the most lamproitic Variscan intrusion. Lithos 121, 74-86. https://doi.org/10.1016/j.lithos.2010.10.005.

Krmíček, L., Romer, R.L., Timmerman, M.J., Ulrych, J., Glodny, J., Přichystal, A., Sudo, M., 2020. Long-lasting (65 Ma) regionally contrasting late- to post-orogenic Variscan mantle-derived potassic magmatism in the Bohemian Massif. J. Petrol. 61, 7. https://dx.doi: 10.1093/petrology/egaa072.

Krmíček, L., Romer, R.L., Ulrych, J., Glodny, J., Prelević, D., 2016. Petrogenesis of orogenic lamproites of the Bohemian Massif: $\mathrm{Sr}-\mathrm{Nd}-\mathrm{Pb}-\mathrm{Li}$ isotope constraints for Variscan enrichment of ultra-depleted mantle domains. Gondwana Res. 35, 198-216. https://doi.org/10.1016/j.gr.2015.04.012. 
La Flèche, M.R., Camiré, G., Jenner, G.A., 1998. Geochemistry of post-Acadian, Carboniferous continental intraplate basalts from the Maritimes Basin, Magdalen islands, Quebec, Canada. Chem. Geol. 148, 115-136. https://doi.org/10.1016/S00092541(98)00002-3.

Lahaye, Y., Blais, S., Auvray, B., Ruffet, G., 1995. Le volcanisme fissural paléozoïque du domaine nord-armoricain. Bull. Soc. géol. France 166, 601-612. https://dx.doi.org/10.2113/gssgfbull.166.5.601.

Langer, K., 1971. Synthesis and properties of gallium-bearing cordierite, $\mathrm{Mg}_{2}\left(\mathrm{Al}_{4}\right.$ $\left.{ }_{x} \mathrm{Ga}_{\mathrm{x}} \mathrm{Si}_{5} \mathrm{O}_{18}\right)$. Am. Mineral. 56, 1689-1698.

Le Bas, M.J., 2007. Igneous rock classification revisited 4: Lamprophyres. Geol. Today 23 (5), 167-168. https://dx.doi.org/10.1111/j.1365-2451.2007.00627.x.

Le Bas, M.J. and Streckeisen, A.L. 1991. The IUGS systematics of igneous rocks. J.Geol. Soc. 148, 825-833. https://doi.org/10.1144/gsjgs.148.5.0825.

Leake, B.E., Woolley, A.R., Arps, C.E.S., Birch, W.D., Gilbert, M.C., Grice, J.D., Hawthorne, F.C., Kato, A., Kisch, H.J., Krivovichev, V.G., Linthout, K., Laird, J., Mandarino, J.A., Maresch, W.V., Nickel, E.H., Rock, N.M.S., Schumacher, J.C., Smith, D.C., Stephenson, N.C.N., Ungaretti, L., Whittaker, E.J.W., Youzhi, G., 1997. Nomenclature of amphiboles: Report of the Subcommittee on Amphiboles of the International Mineralogical Association, Commission on New Minerals and Mineral Names. Am. Mineral. 82, 1019-1037. http://dx.doi.org/10.1180/minmag.1997.061.405.13

Le Gall, B., 1990. Evidence of an imbricate crustal thrust belt in the Southern British Variscides. Contributions of Southwestern Approaches Traverse (SWAT) deep seismic reflection profiling recorded through the English Channel and the Celtic Sea. Tectonics 9(2), 283-302. https://doi.org/10.1029/TC009i002p00283. 
Le Gall, B., Authemayou, C., Ehrhold, A., Paquette, J.-L., Bussien, D., Chazot, G., et al., 2014. LiDAR offshore structural mapping and $\mathrm{U} / \mathrm{Pb}$ zircon/monazite dating of Variscan strain in the Léon metamorphic domain, NW Brittany. Tectonophysics 630, 236-250. https://doi.org/10.1016/j.tecto.2014.05.026.

Le Maitre, R. W. (ed.), 2002. Igneous rocks: A classification and glossary of terms: Recommendations of the International Union of Geological Sciences, Subcommission on the Systematics of Igneous Rocks. Cambridge University Press, Cambridge.

Li, Z.-H., Liu, M., Gerya, T., 2016. Lithosphere delamination in continental collisional orogens : A systematic numerical study. J. Geophys. Res. Solid Earth 121, 5186-5211. http://dx.doi.org/10.1002/2016JB013106.

Ma, L., Jiang, S.-Y., Hou, M.L., Dai, B.-Z., Jiang, Y.-H., Yang, T., Zhao, K.-D., Pu, W., Zhu, Z.-Y., Xu, B., 2014. Geochemistry of Early Cretaceous calc-alkaline lamprophyres in the Jiaodong Peninsula: Implication for lithospheric evolution of the eastern North China Craton. Gondwana Res. 25, 859-872. http://dx.doi.org/10.1016/j.gr.2013.05.012. Maniar, P.D., Piccoli, P.M., 1989. Tectonic discriminations of granitoids. Geol. Soc. Am. Bull. 101, 635-643. http://dx.doi.org/10.1130/00167606(1989)101<0635:TDOG>2.3.CO;2.

Marcoux, E., Cocherie, A., Ruffet, G., Darboux, J.-R., Guerrot, C., 2009. Géochronologie revisitée du dôme du Léon (Massif armoricain, France). Géol. France 1, 19-40.

Matte, P., 2001. The Variscan collage and orogeny (480-290 Ma) and the tectonic definition of the Armorica microplate: a review. Terra Nova 13, 122-128. https://doi.org/10.1046/j.1365-3121.2001.00327.x

Mitchell, R.H., 1994. The lamprophyre facies. Mineral. Petrol. 51, 137-146. https://dx.doi.org/10.1007/BF01159724. 
Morimoto, N., Fabries, J., Ferguson, A.K., Ginzburg, I.V., Ross, M., Seifert, F.A., Zussman, J., Aoki, K., Gottardi., G., 1988. Nomenclature of pyroxenes. Mineral. Mag. 52 (367), 535-550. https://doi.org/10.1180/minmag.1988.052.367.15.

Nimis, P., 1999. Clinopyroxene geobarometry of magmatic rocks. Part 2. Structural geobarometers for basic to acid, tholeiitic and mildly alkaline magmatic systems. Contrib. Mineral. Petrol. 135, 62-74. https://doi.org/10.1007/s004100050498.

Orejana, D., Villaseca, C., Kristoffersen, M., 2020. Geochemistry and geochronology of mafic rocks from the Dpanish Central System: Constraints on the mantle evolution beneath central Spain. Geosci. Front. 11 (5), 1651-1667. https://doi.org/10.1016/j.gsf.2020.01.002.

Orozco-Garza, A., Dostal, J., Keppie, J.D., Paz-Moreno, F.A., 2013. Mid-Tertiary (25-21 Ma) lamprophyres in NW Mexico derived from subduction-modified subcontinental lithospheric mantle in an extensional backarc environment following steepening of the Benioff zone. Tectonophysics 590, 59-71. http://dx.doi.org/10.1016/j.tecto.2013.01.013.

Owen, J.P., 2008. Geochemistry of lamprophyres from the Western Alps, Italy: implications for the origin of an enriched isotopic component in the Italian mantle. Contrib. Mineral. Petrol. 155, 341-362. https://dx.doi.org/10.1007/s00410-007-0246-0.

Pál-Molnár, E., Batki, A., Ódri, Á, Kiss, B., Almási, E., 2015. Geochemical implication for the magma origin of granitic rocks from the Ditrău Alcaline Massif (Eastern Carpathians, Romania). Geol. Croat. 68 (1), 51-66. https://dx.doi:10.4154/gc.2015.04. Philpotts, A.R., Carroll, M., Hill, J.M., 1996. Crystal-mush compaction and the origin of pegmatitic segregation sheets in a thick flood-basalt flow in the Mesozoic Hartfort Basin, Connecticut. J. Petrol. 37, 811-836. https://doi.org/10.1093/petrology/37.4.811. 
Plank, T., Langmuir, C.H., 1998. The chemical composition of subducting sediment and its consequences for the crust and mantle. Chem. Geol. 145, 325-394. https://doi.org/10.1016/S0009-2541(97)00150-2.

Plusquellec, Y., Rolet, J., Darboux, J.R. (coordinators), 1999. Geological map of France, sheet Châteaulin (310). BRGM, Orléans, scale 1:50,000.

Prelević, D., Foley, S.F., Cvetković, V., Romer, R.L., 2004. Origin of minette by mixing of lamproite and dacite magmas in Veliki Majdan, Serbia. J. Petrol. 45 (4), 759-792. https://doi.org/10.1093/petrology/egg109.

Ramesh Kumar, P.V., Raju, K.K.V.S., Ganga Roa, B.S., 1995. Surinamite (Be, B, Ga) from cordierite gneisses of eastern ghat mobile belt, India. Current Sci. 69, 763-767. https://dx.doi.org/10.2307/24097066.

Ridolfi, F., Renzulli, A., 2012. Calcic amphiboles in calc-alkaline and alkaline magmas: thermobarometric and chemometric empirical equations valid up to $1,130{ }^{\circ} \mathrm{C}$ and 2.2 GPa. Contrib. Mineral. Petrol. 163, 877-895. https://dx.doi.org/ 10.1007/s00410-0110704-6.

Robinson, J.A.C., Wood, B.J., 1998. The depth of the spinel to garnet transition at the peridotite solidus. Earth Planet. Sci. Lett. 164, 277-284. https://dx.doi.org/10.1016/S0012-821X(98)00213-1.

Rock, N.M.S., 1984. The nature and origin of calc-alkaline lamprophyres: minettes, vogesites, kersantites and spessartites. Earth Env. Sci. T. R. So. 74, 193-227. https://doi.org/10.1017/S0263593300013663.

Rock, N.M.S., 1987. The nature and origin of lamprophyres: an overview. In: Fitton, J.G., Upton, B.G.J. (Eds.), Alkaline Igneous Rocks. Geol. Soc. Spec. Publ., Geol. Soc. London 30, 191-226. 
Rock, N.M.S., 1991. Lamprophyres. Blackie and Son Ltd., Glasgow-London, United Kingdom.

Rolet, J., Gresselin F., Jegouzo, P., Ledru, P., Wyns, R., 1994. Intracontinental Hercynian events in the Armorican Massif. In: Keppie, J.D. (Ed.), Pre-Mesozoic geology in France and related areas. IGCP-Project 233 (Terranes in the Circum-Atlantic Paleozoic orogens). Springer-Verlag, Berlin, Heidelberg, 195-219. https://dx.doi.org/10.1007/978-3-642-84915-2_20.

Rolet, J., Thonon, P., 1979. La semelle d'un charriage hercynien majeur effondrée par un réseau de fractures en régime coulissant dextre : sa mise en évidence grâce aux marqueurs filoniens de la Rade de Brest (Massif armoricain). C. R. Acad. Sci. Paris (D), 287, 1099-1102.

Rosenbusch, H., 1896. Mikroskopiche physiographie der mineralien und gesteine. Vol. II: Massige gesteine. Schweizbart, Stuttgart. $3^{\text {rd }}$ ed.

Rudnick, R.L., Fountain, D.M., 1995. Nature and composition of the continental crust: A lower crustal perspective. Rev. Geophys. 33, 267-309. https://dx.doi.org/10.1029/95RG01302.

Schulz, B., 2013. Monazite EMP-Th-U-Pb age pattern in Variscan metamorphic units in the Armorican Massif (Brittany, France). German J. Geosci. 164, 313335. https://dx.doi.org/10.1127/1860-1804/2013/0008.

Seifert, Th., 2008. Metallogeny and petrogenesis of lamprophyres in the Mid-European Variscides. IOS Press BV, Amsterdam, Netherlands.

Shore, M., Fowler, A.D., 1996. Oscillatory zoning in minerals: a common phenomenon. Can. Mineral. 34, 1111-1126. 
Sims K.W.W., De Paolo D.J. (1997) Inferences about mantle magma sources from incompatible element concentration ratios in oceanic basalts. Geochim. Cosmochim. Acta 61, 765-784. https://dx.doi.org/10.1016/S0016-7037(96)00372-9.

Soder, C.G., Romer, R.L., 2018. Post-collisional potassic-ultrapotassic magmatism of the Variscan Orogen: Implications for mantle metasomatism during continental subduction. J. Petrol. 59 (6), 1007-1034. http://dx.doi.org/10.1093/petrology/egy053.

Speer, J.A., 1984. Micas in igneous rocks. In: Bailey S.W. (ed.) Micas. Reviews in Mineralogy 13, 299-356. Mineralogical Society of America, Blacksburg, Virginia. Stepanov, A.S., Hermann, J., 2013. Fractionation of Nb and Ta by biotite and phengite: Implications for the "missing Nb paradox". Geology 41, 303-306. https://dx.doi.org/10.1130/G33781.1.

Streckeisen, A., 1976. To each plutonic rock its proper name. Earth Sci. Rev. 12, 1-33. https://dx.doi.org/10.1016/0012-8252(76)90052-0.

Tappe, S., Foley, S.F., Jenner, G.A., Kjarsgaard, B.A., 2005. Integrating ultramafic lamprophyres into the IUGS classification of igneous rocks: Rationale and implications. J. Petrol. 46 (9), 1893-1900. http://dx.doi.org/10.1093/petrology/egi039.

Tappe, S., Smart, K.A., Stracke, A., Romer, R.L., Prelević, D., van den Bogaard, P., 2016. Melt evolution beneath a rifted craton edge: ${ }^{40} \mathrm{Ar} /{ }^{39} \mathrm{Ar}$ geochronology and $\mathrm{Sr}-\mathrm{Nd}-\mathrm{Hf}-\mathrm{Pb}$ isotope systematics of primitive alkaline basalts and lamprophyres from the SW Baltic Shield. Geochim. Cosmochim. Acta 173, 1-36. http://dx.doi.org/10.1016/j.gca.2015.10.006.

Taylor, S.R., McLennan, S.M., 1985. The Continental Crust: its Composition and Evolution. Blackwell., Oxford.

Thonon, P. (1973). Quelques roches filoniennes de la rade de Brest (Première partie). Penn ar Bed 72, 17-24. 
Thonon, P. (1975). Quelques roches filoniennes de la rade de Brest (Deuxième partie). Penn ar Bed 80, 6-16.

Turpin, L., Velde, D., Pinte, G., 1988. Geochemical comparison between minettes and kersantites from the Western European Hercynian orogen: trace element and $\mathrm{Pb}-\mathrm{Sr}-\mathrm{Nd}$ isotope constraints on their origin. Earth Planet. Sci. Lett. 87, 73-86. https://dx.doi.org/10.1016/0012-821X(88)90065-9.

Ubide, T., Caulfield, J., Brandt, C., Bussweiler, Y., Mollo, S., Di Stephano, F., Nazzari, M., Scarlato, P., 2019. Deep magma storage revealed by multi-method elemental mapping of clinopyroxene megacrysts at Stromboli Volcano. Front. Earth Sci. 7, 239. http://dx.doi.org/10.3389/feart.2019.00239.

Ubide, T., Galé, C., Arranz, E., Lago, M., Larrea, P., 2014. Clinopyroxene and amphibole crystal populations in a lamprophyre sill from the Catalonian Coastal Ranges (NE Spain): A record of magma history and a window to mineral-melt partitioning. Lithos 184-187, 225-242. http://dx.doi.org/10.1016/j.lithos.2013.10.029.

Velde, D., 1971. Les kersantites : étude des lamprophyres à plagioclase et biotite. Bull. Soc. française Minéral. Cristal. 94, 411-426. http://dx.doi.org/10.3406/bulmi.1971.6596.

Velde, D., 1968. Les transformations de l'olivine dans les lamprophyres et lamproïtes : une étude de la pilite. Bull. Soc. géol. France 7 (X), 601-612. http://dx.doi.org/10.2113/gssgfbull.S7-X.5.601.

Villey, M. (coordinator), 1982. Geological map of France, sheet Carhaix (277). BRGM, Orléans, scale 1:50,000. 


\section{Figures}

Figure 1. Structural map and main tectonostratigraphic units of the European Variscan belt. Adapted from Ballèvre et al. (2009), Franke et al. (2017), Dijkstra and Hatch (2018), Soder and Romer (2018), and Authemayou et al. (2019).

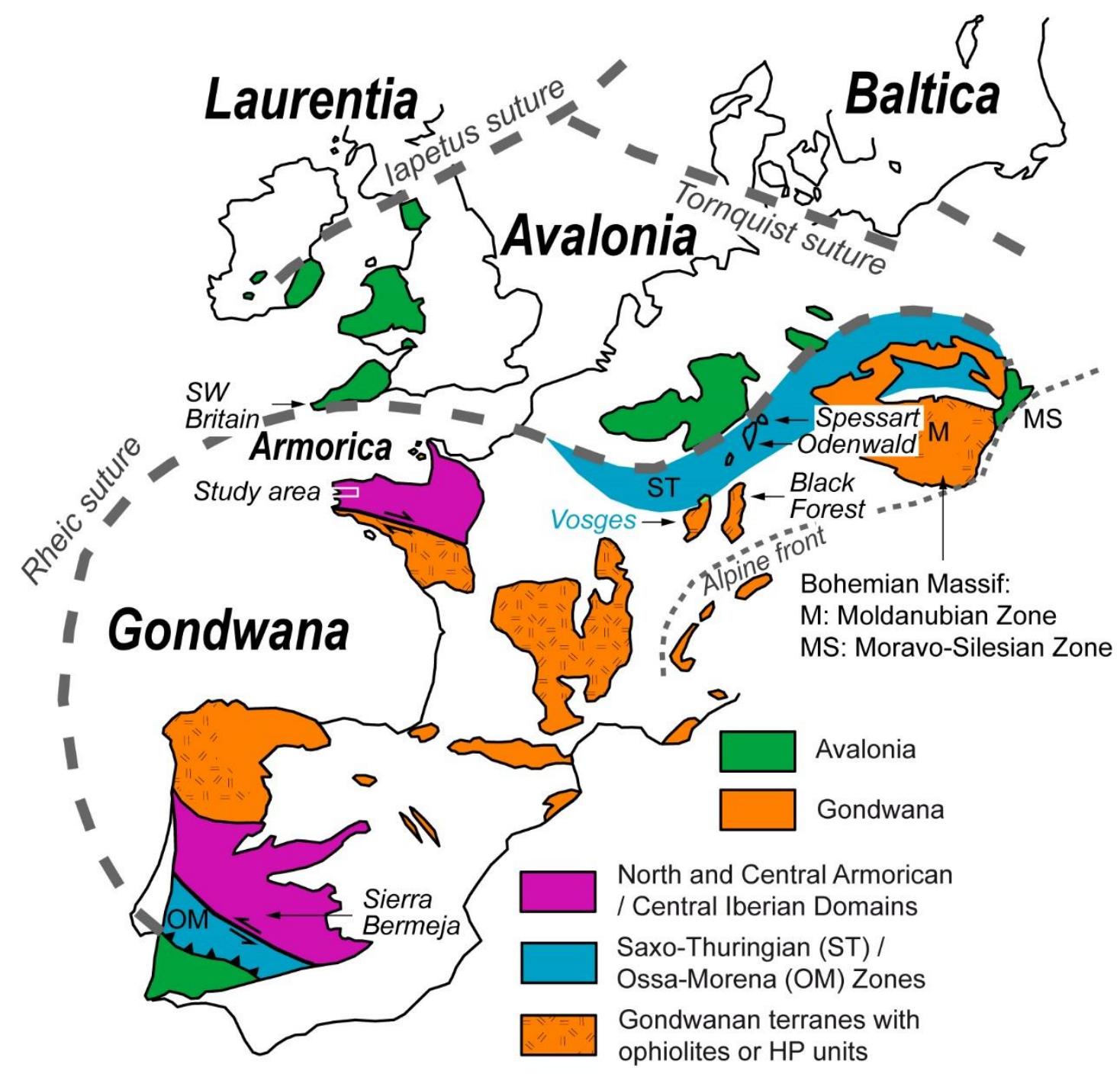

Caroff et al. Fig. 1

Figure 2. Geological features of the studied area. (a) Sketch geological map of the Armorican Massif, showing Tournaisian/Visean mafic bodies (from Lahaye et al., 1995; Caroff et al., 1996, 2011, 2016, 2020; Barboni and Bussi, 2013; see text for explanations). NAD: North- 
Armorican Domain; CAD: Central-Armorican Domain; SAD: South-Armorican Domain;

NASZ: North-Armorican shear zone; SASZ: South-Armorican shear zone. (b) Sketch geological map of the western part of the Central-Armorican Domain. Purple circles: sample location. Dike/sill network not drawn in inset Fig. 2c. (c) More detailed geological map of the Brest Bay. (b) and (c) from Thonon (1973, 1975), Chauris and Plusquellec $(1975,1980)$, Babin and Darboux (1982), Villey (1982), Castaing (1987), and Plusquellec et al. (1999). 

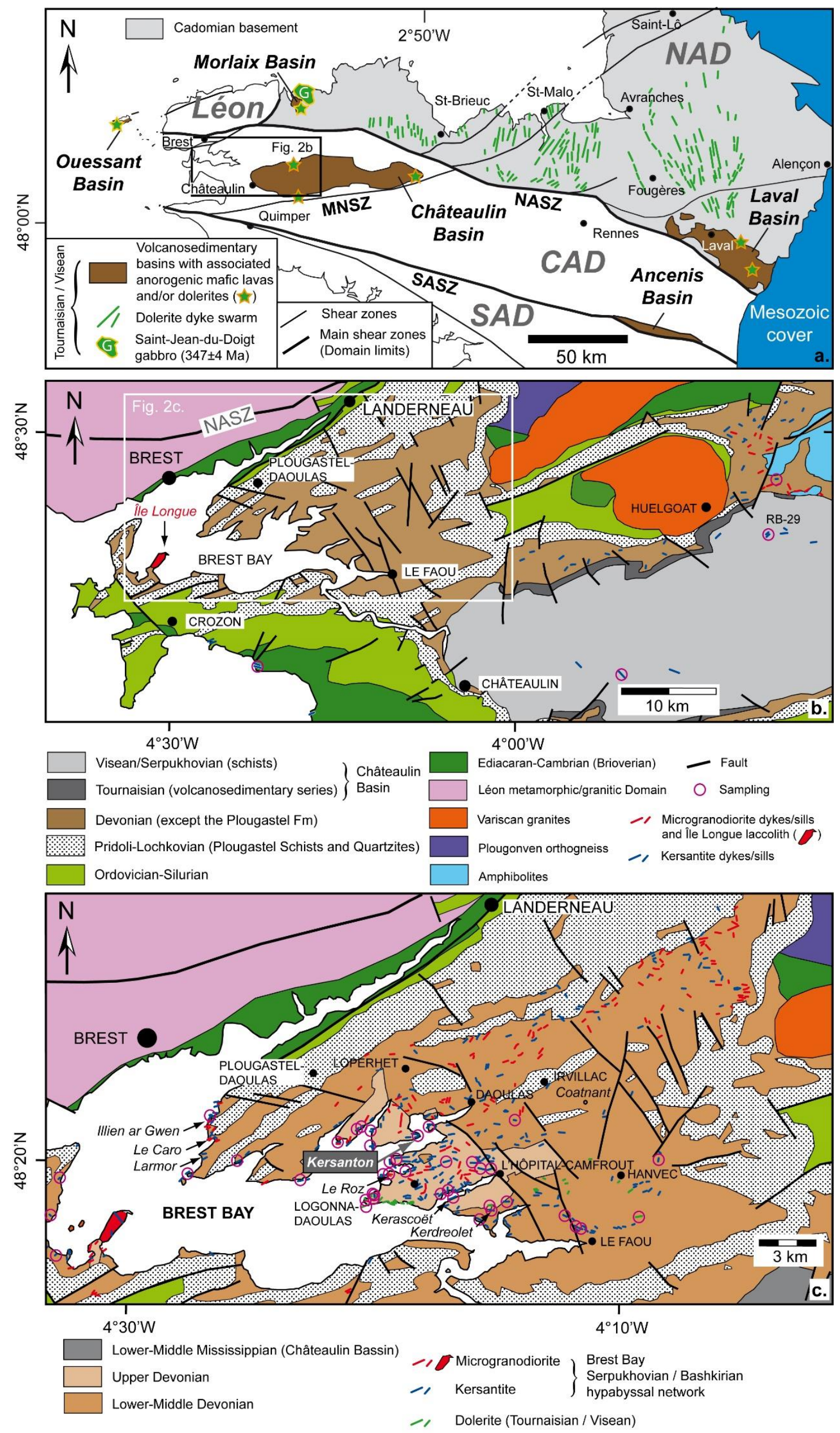
Figure 3. Kersantites and microgranodiorites in the field (locations in Fig. 2c). (a) (b) (c) Schematic geological cross-sections. (a) Kersantite sheet involved in a $2^{\text {nd }}$ generation fold structure postdating the main schistosity (Kerdréolet, L'Hôpital Camfrout). (b) Moderatelydipping kersantite sheet injected along a minor SSE-verging thrust structure (Larmor, Plougastel-Daoulas). (c) Thin microgranodiorite sill intrusion emplaced along a northwesterly-directed shear structure (Le Caro, Plougastel-Daoulas). (d) Margins of a shallowly-dipping sill-like kersantite intrusion subsequently reactivated by top-to-the-E shearing (Illien ar Gwen, Plougastel-Daoulas). Hammer for scale. (e) (f) (g) (h) Magmatic and tectonic structures in the basal part of a sheared kersantite sill (Kerascoët, L'Hôpital Camfrout). Hammer for scale (encircled). (i) Quarry face in a microgranodiorite sill (Le Roz, Logonna-Daoulas). Sledgehammer for scale (encircled). (j) An example of the famous Breton Calvaries with a base in microgranodiorite (Le Roz Stone), and shafts and statues in kersantite (Coatnant, Irvillac). 

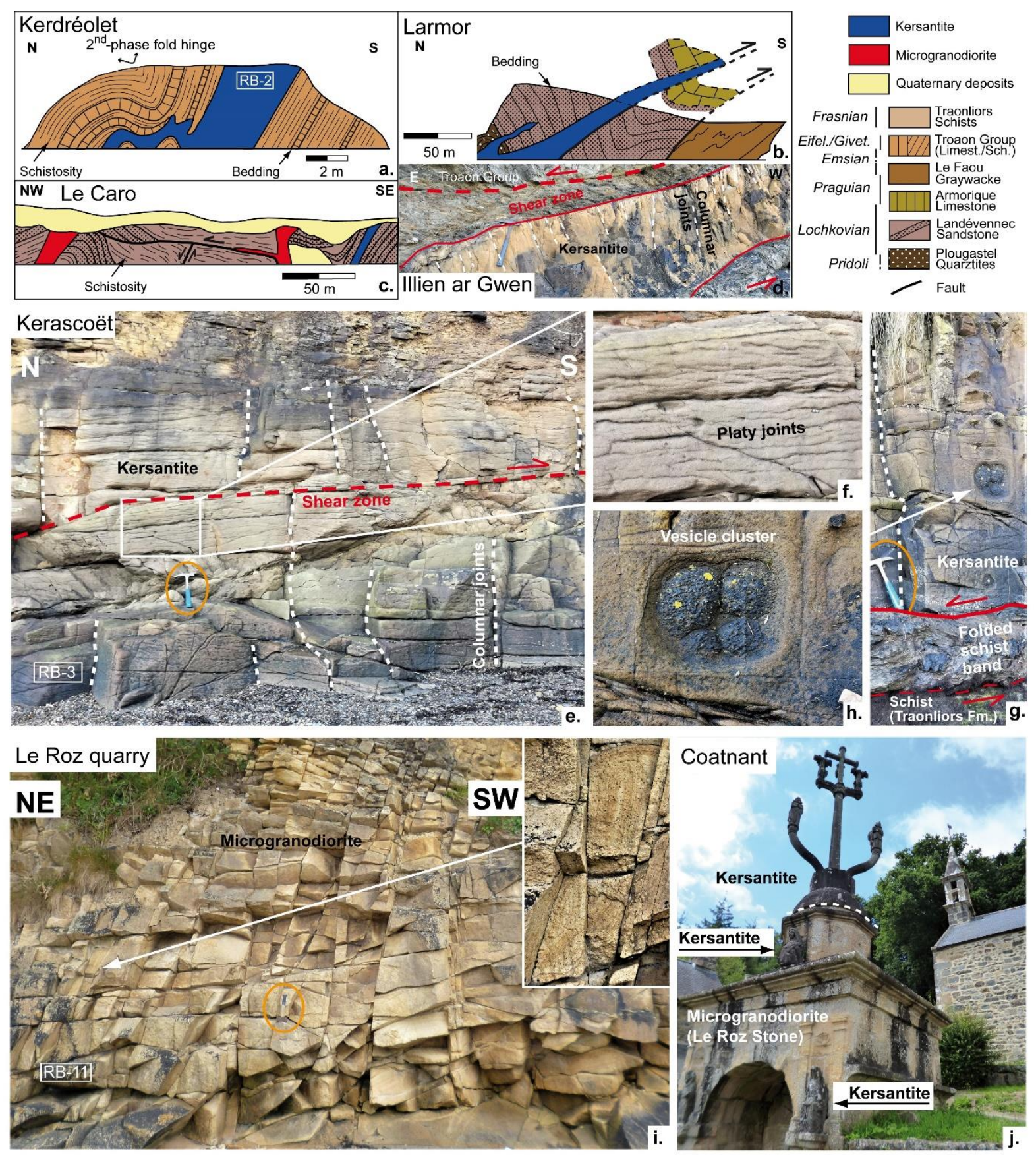

Caroff et al. Fig. 3

Figure 4. Mineral discrimination diagrams for W-Armorican kersantites, compared with data from other kersantites (Rock, 1984; Sudetes: Awdankiewicz, 2007; Sierra Bermeja:

Errandonea-Martin et al., 2018); a.p.f.u.: atoms per formula unit; K. for kersantites. (a)

Chemical variations of amphiboles (brown euhedral phenocrysts in sample RB-41 and green microcrysts in RB-43) in the $\mathrm{Mg} /\left(\mathrm{Mg}+\mathrm{Fe}^{2+}\right)$ vs. Si diagram. All values in cations per formula unit calculated to $23 \mathrm{O}$ and $13 \mathrm{CNK}$ (total cations except $\mathrm{Ca}$, $\mathrm{Na}$ and $\mathrm{K}=13$ ). Nomenclature 
from Leake et al. (1997). The pressure ranges indicated in MPa have been calculated from the amphibole compositions in both samples by using the empirical method of Ridolfi and Renzulli (2012) (see text). (b) Chemical variations of clinopyroxenes in the $\mathrm{Ca}-\mathrm{Mg}-\mathrm{Fe}$ diagram. All values in cations per formula unit calculated to $6 \mathrm{O}$ and 4 cations. Nomenclature from Morimoto et al. (1988). (c) Chemical variation of dark micas in the Al-Mg-Fe diagram. All values in cations per formula unit calculated to 22 O. Nomenclature from Speer (1984).

(d) Chemical variation of chlorites in the Hey (1954) diagram. All values in cations per formula unit calculated to $28 \mathrm{O}$.

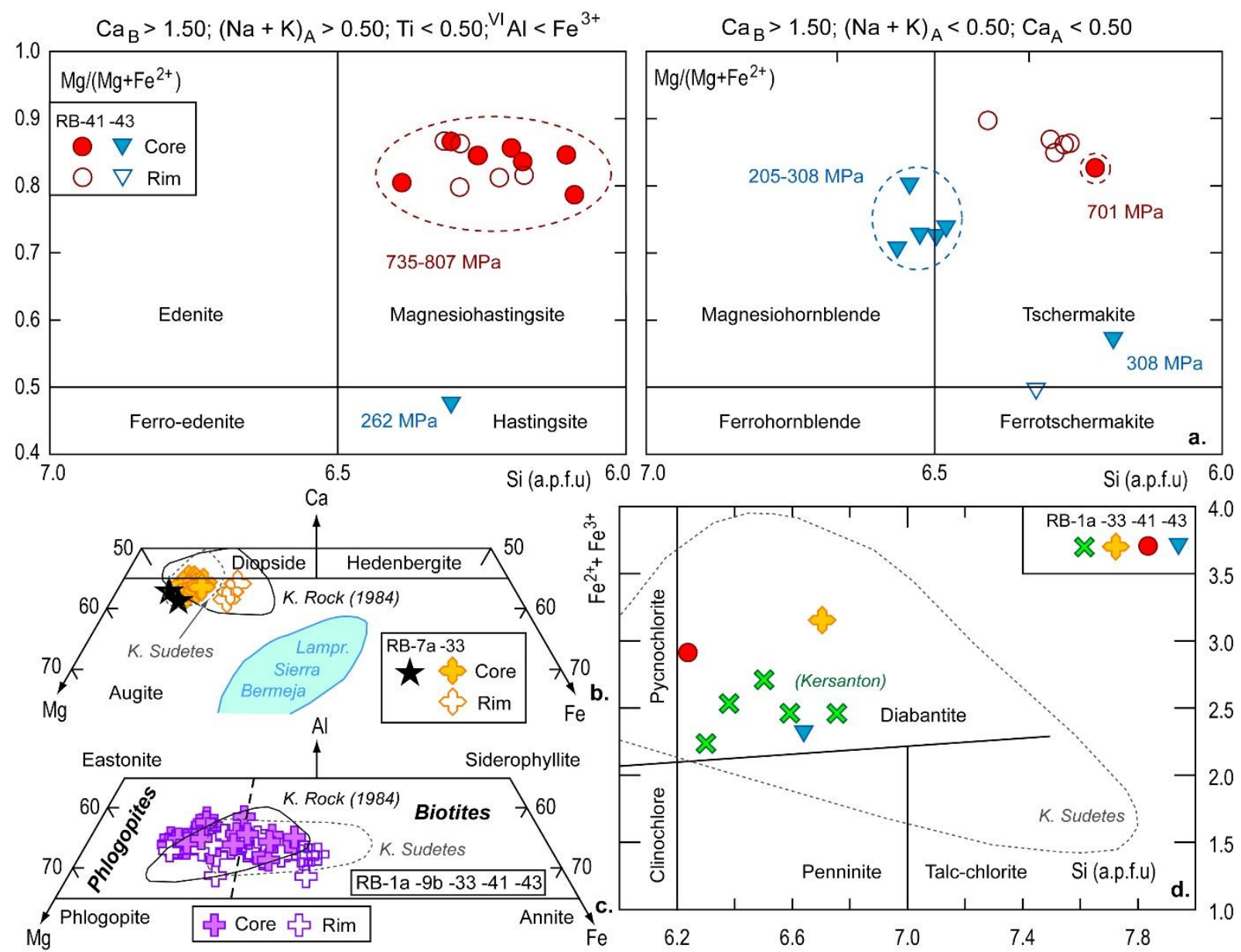


Figure 5. X-ray compositional maps collected with the Cameca SX-100 electron microprobe

(Microsonde Ouest, Brest, France), illustrating the clinopyroxene zonings in the kersantite

RB-33 (Hanvec).

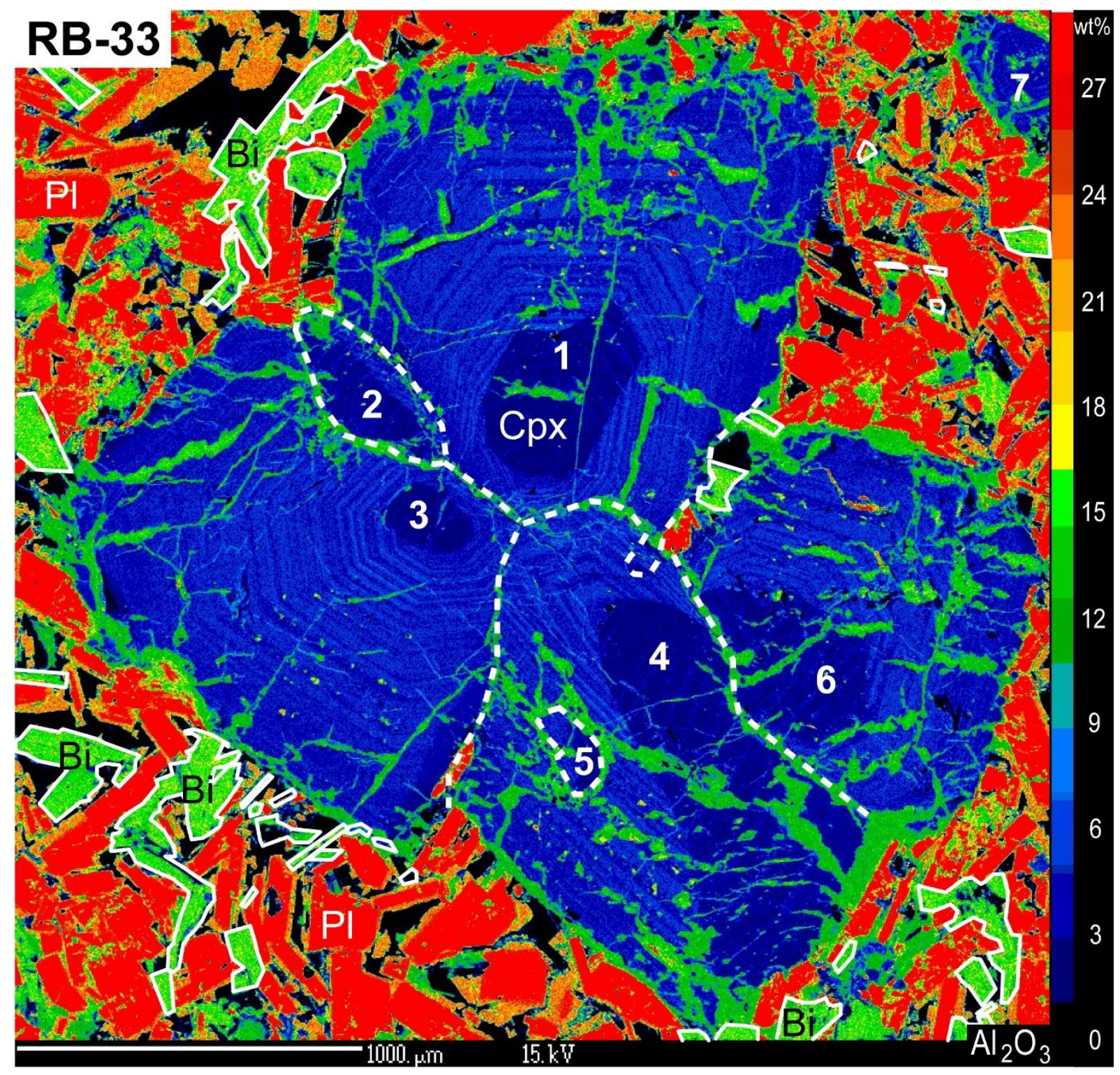

Caroff et al. Fig. 5

Figure 6. Whole rock major element discrimination diagrams for W-Armorican kersantites and microgranodiorites, compared with kersantites (K.) from other Variscan kersantites (Bohemian Massif: Krmíček et al., 2020; Odenwald/Spessart and Black Forest: Soder and Romer, 2018; Sierra Bermeja: Errandonea-Martin et al., 2018; SW-England: Dijkstra and Hatch, 2018); n: number of samples. (a) Total alkali vs. silica discrimination diagram of Le 
Bas and Streckeisen (1991). (b) Triangular $\mathrm{CaO}-\mathrm{SiO}_{2} / 10-4 \mathrm{TiO}_{2}$ plot after Rock (1987). (c)

$\mathrm{K}_{2} \mathrm{O}$ vs. $\mathrm{Na}_{2} \mathrm{O}$ classification diagram after Foley et al. (1987). (d) Shand's Index diagram

(Maniar and Piccoli, 1989); A/NK: molar ratio of $\mathrm{Al}_{2} \mathrm{O}_{3} /\left(\mathrm{Na}_{2} \mathrm{O}+\mathrm{K}_{2} \mathrm{O}\right)$; A/CNK: molar ratio of $\mathrm{Al}_{2} \mathrm{O}_{3} /\left(\mathrm{CaO}+\mathrm{Na}_{2} \mathrm{O}+\mathrm{K}_{2} \mathrm{O}\right)$.
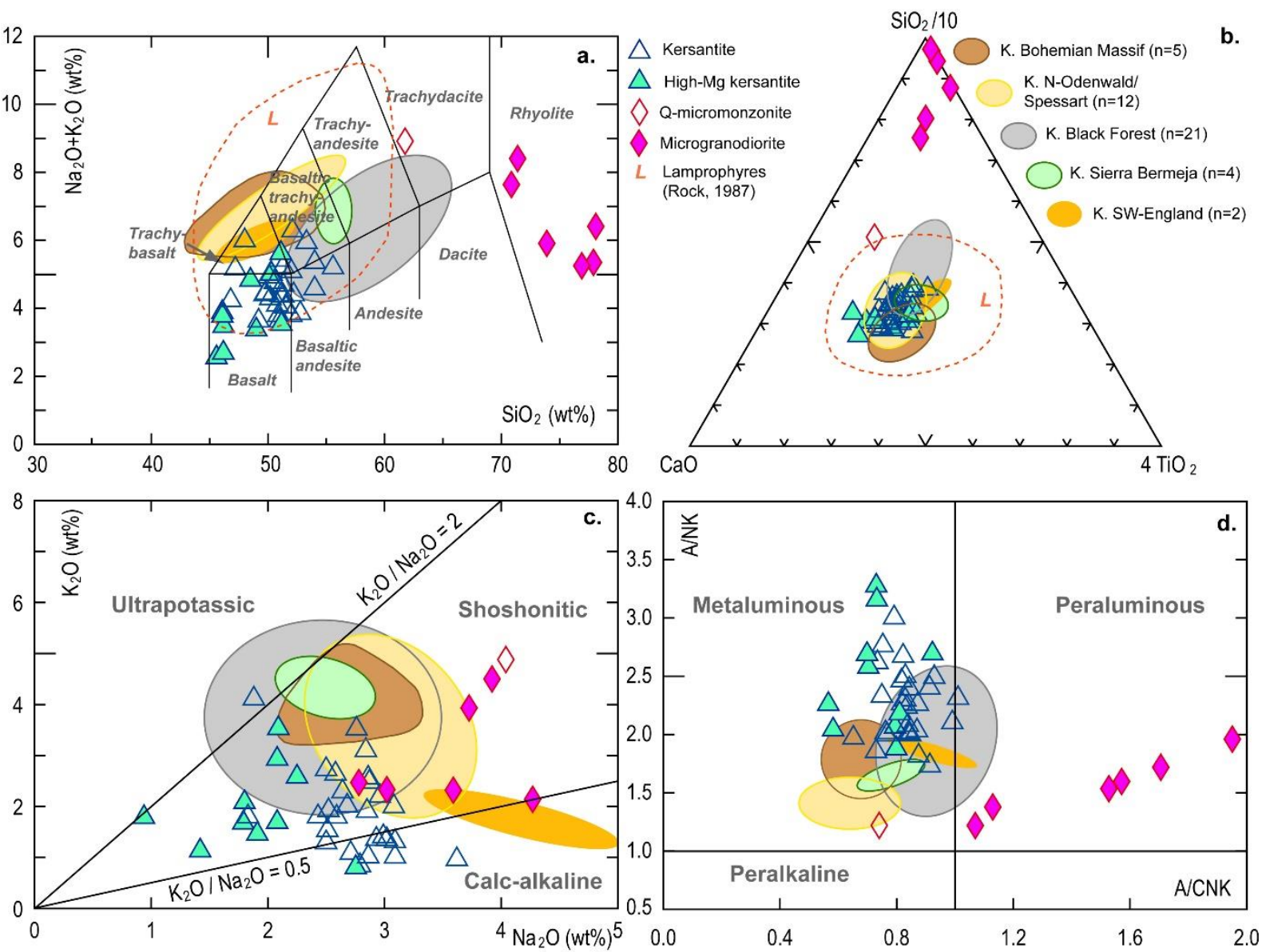

Caroff et al. Fig. 6

Figure 7. Whole rock major element variation diagrams for W-Armorican kersantites and microgranodiorites. (a) (b) (c) $\mathrm{MgO}, \mathrm{Fe}_{2} \mathrm{O}_{3} *$ and $\mathrm{Na}_{2} \mathrm{O}$ vs. $\mathrm{SiO}_{2}$ variation diagrams, respectively. The dashed arrows show the differentiation path from the kersantite RB-12a to its Q-micromonzonitic segregation pod RB-12b. 


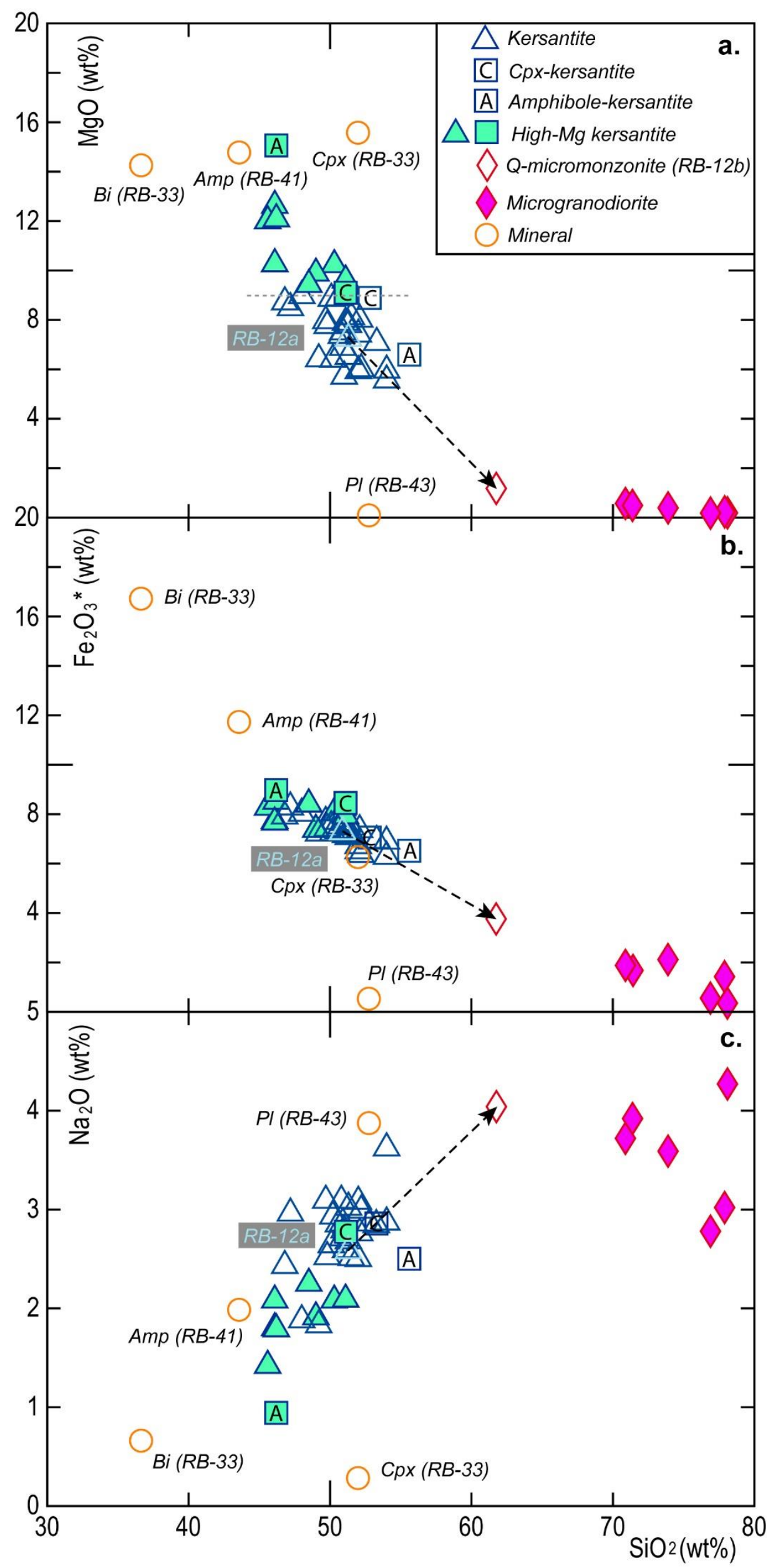

Caroff et al. Fig. 7 
Figure 8. Spider diagrams normalized to primitive mantle (Hofmann, 1988). (a) W-Armorican kersantites (plus the Q-micromonzonite RB-12b) and dolerites; GLOSS (GLObal Subducted Sediment composition) from Plank and Langmuir (1998). (b) Kersantites (K.) from other European Variscan localities (references in Fig. 6). (c) Armorican microgranodiorites. The range of kersantite compositions is shown as a field. 


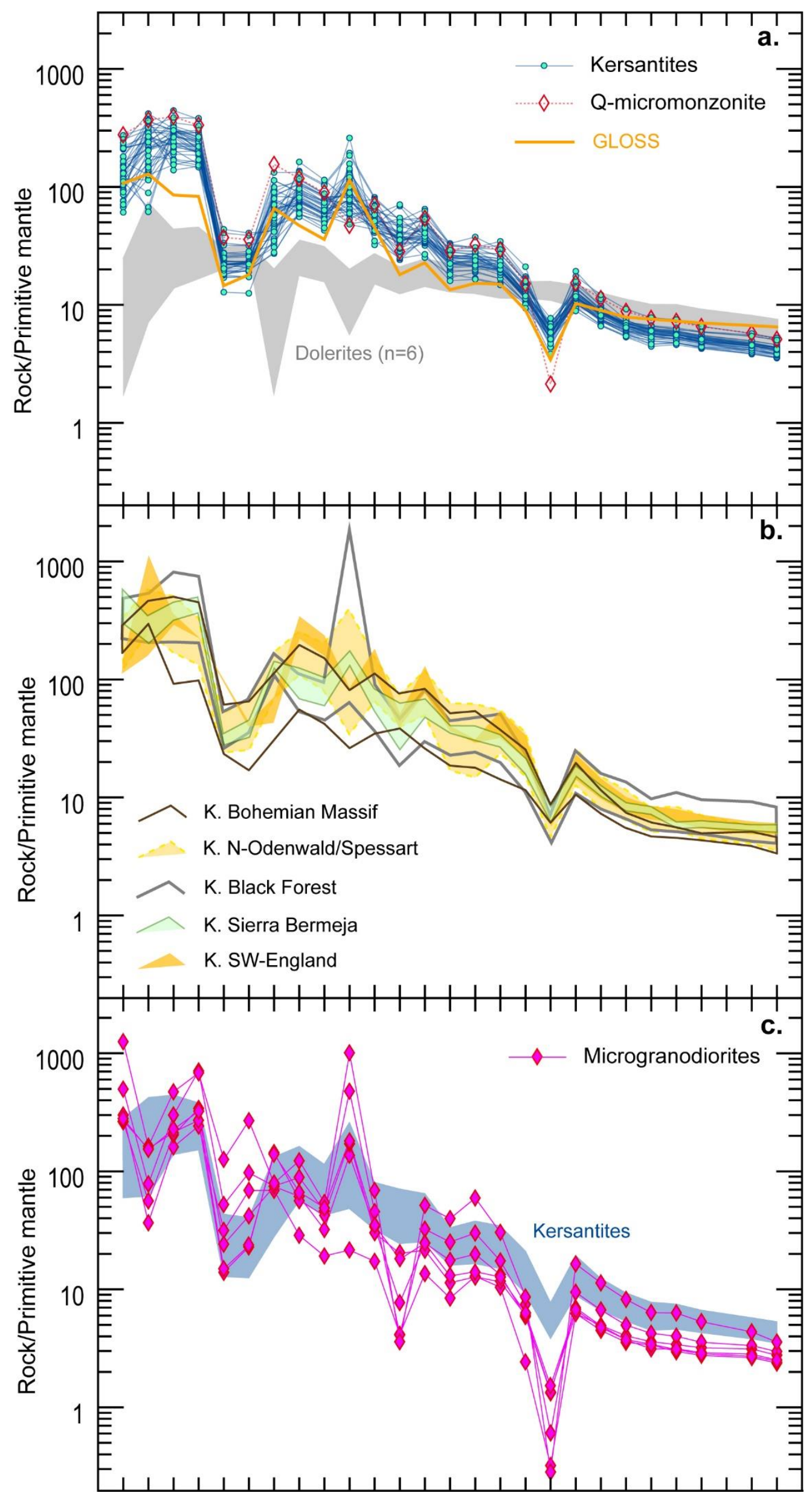

RbBa Th U Nb Ta K La Ce Pb Pr Sr Nd Zr HfSmEu Ti Gd Tb Dy Y Ho ErTm Yb Lu

Caroff et al. Figure 8 
Figure 9. Initial $\varepsilon_{\mathrm{Nd}}$ vs. initial ${ }^{87} \mathrm{Sr} /{ }^{86} \mathrm{Sr}$ isotope diagram showing W-Armorican kersantites, Qmicromonzonite and microgranodiorites $\left({ }^{87} \mathrm{Sr} /{ }^{86} \mathrm{Sr}\right.$ data available only for the Île Longue samples), compared with kersantites from the Bohemian Massif (M: Moldanubian Zone; ST: Saxo-Thuringian Zone; Krmíček et al., 2020), the N-Odenwald, the Vosges and Black Forest (Soder and Romer, 2018), and the SW-England region (Dijkstra and Hatch, 2018). Mantle array; UR (Uniform Reservoir, Sr) and CHUR (CHondritic Uniform Reservoir, Nd) from Dijkstra and Hatch (2018). The Armorican Tournaisian/Visean mafic rocks (Saint-Jean-duDoigt gabbro: Caroff et al., 2011 and Barboni and Bussy, 2013; Châteaulin and Ouessant basalts: Caroff et al., 2016) have initial $\varepsilon_{\mathrm{Nd}}$ ranging from 2 and 6. Inset: initial $\varepsilon_{\mathrm{Nd}} \mathrm{vs}$. age (Ma) for lamprophyres and associated lampyrites/lamproites from the Bohemian Massif (Krmíček et al., 2020).

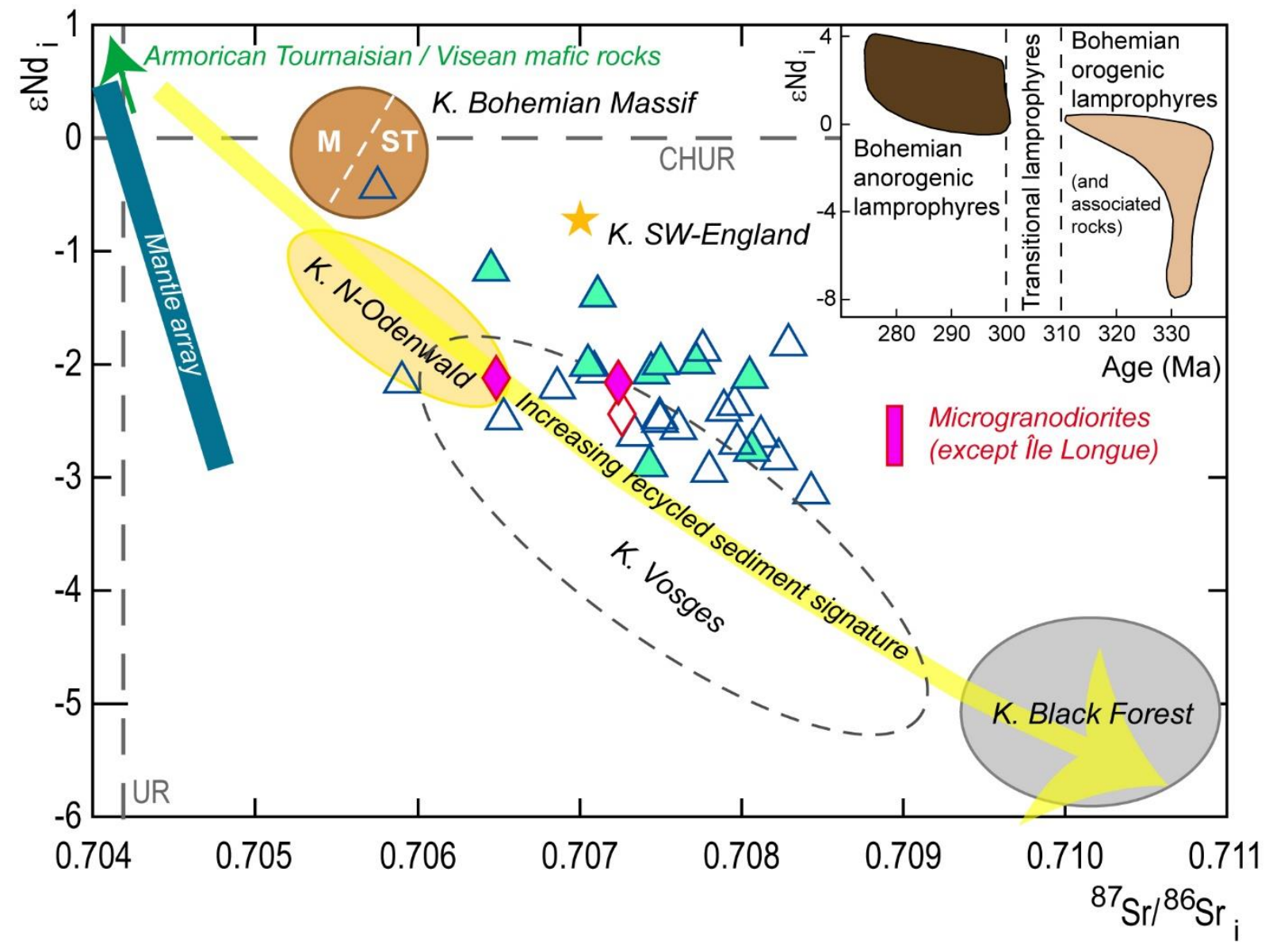

Caroff et al. Fig. 9 
Figure 10. Trace and major element ratios for W-Armorican kersantites, compared with data from other Variscan kersantites (symbols, colors, and references as in Fig. 6). (a) N-MORBnormalized Dy/Yb vs. $\mathrm{K}_{2} \mathrm{O} / \mathrm{Na}_{2} \mathrm{O}$ (logarithmic scale) diagram, from Dijkstra and Hatch (2018). (b) Rb/Sr vs. Ba/Rb diagram, from Ma et al. (2014). (c) Dy/Yb vs. K/(1000Yb) diagram. Melting curves from Duggen et al. (2005). Non-modal, point-average fractional partial melting curves are presented for garnet lherzolite $(\mathrm{Ga})$, garnet-facies phlogopite lherzolite (brown dashed lines), garnet-facies amphibole lherzolite (red dashed lines), spinelgarnet transition zone lherzolite $(\mathrm{Ga}+\mathrm{Sp})$, spinel lherzolite $(\mathrm{Sp})$, and spinel-facies amphibole lherzolite (red dotted lines). Percentages indicate degrees of partial melting. Partial melting was modelled by Duggen et al. (2005) with various K contents in the amphibole- and phlogopite-bearing lherzolites (indicated in ppm in the brown and red curves). For distribution coefficients, source composition, lherzolite modal fractions and normative weight fractions of minerals in the partial melts, see Duggen et al. (2005). 

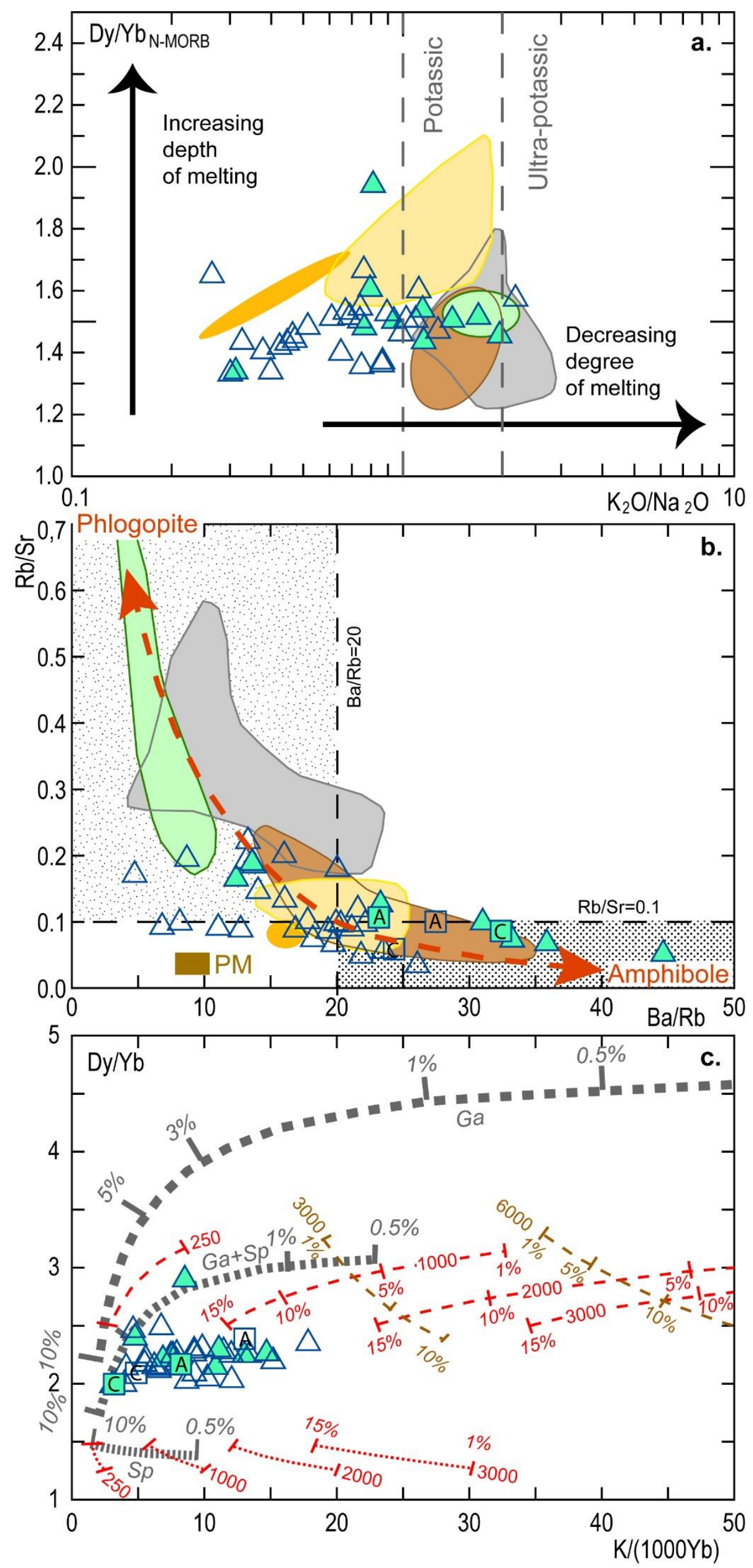

Caroff et al. Fig. 10 
Figure 11. Trace element discrimination diagrams with a logarithmic scale for $\mathrm{W}$-Armorican kersantites (plus the Q-micromonzonite RB-12b) and older dolerites, compared with data from other Variscan kersantites (symbols, colors, and references as in Fig. 6; for the Bohemian kersantites: M: Moldanubian Zone; MS: Moravo-Silesian Zone; ST: SaxoThuringian Zone; Krmíček et al., 2020) and various compositional fields or average values; GLOSS (GLObal Subducted Sediment composition: Plank and Langmuir, 1998). (a) Ce/Pb vs. Ce plotted on a log scale. Mantle $\mathrm{Ce} / \mathrm{Pb}$ ratio of $25 \pm 5$ (in gray lines), MORB and OIB data from Hofmann et al. (1986); references for continental lithospheric mantle, lower and average continental crust, and pelagic sediments: Sims and De Paolo (1997) and Owen (2008). (b) Primitive mantle normalized Hf/Sm vs. Ta/La plotted on a log scale (normalization values: Hofmann, 1988). References for melt-related subduction metasomatism, fluid-related subduction metasomatism, and carbonatite metasomatism in La Flèche et al. (1998). 

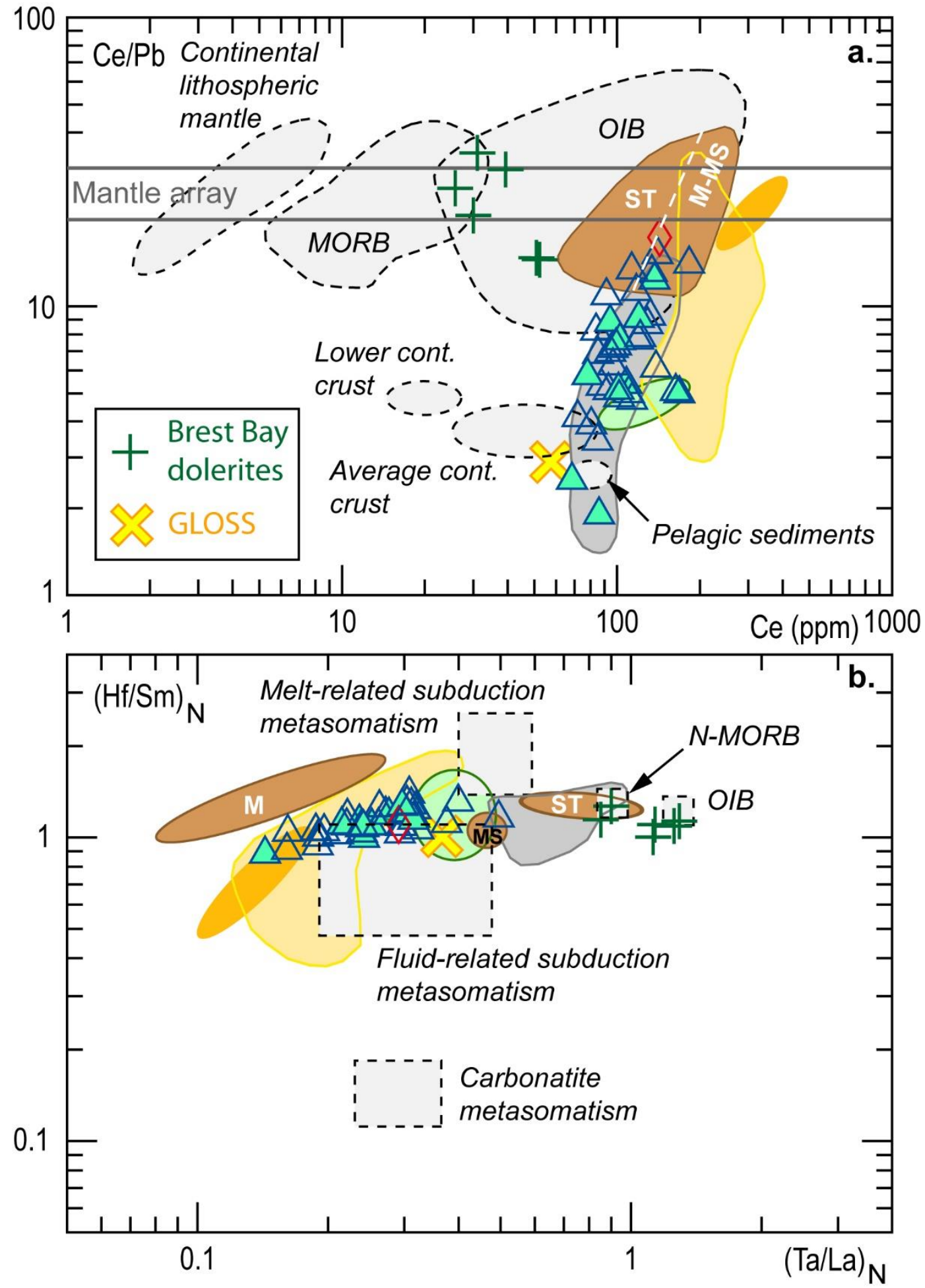

Caroff et al. Fig. 11

Figure 12. Nb/Ta vs. Nb diagram, from Stepanov and Hermann (2013), for W-Armorican kersantites, Q-micromonzonite and microgranodiorites (symbols as in Fig. 6). References for GLOSS as in Fig. 11; BCC: Bulk Continental Crust (Rudnick and Fountain, 1995); UCC: 
Upper Continental Crust (Taylor and McLennan, 1985). For the compositional field references, see Stepanov and Hermann (2013). F: fractional crystallization.

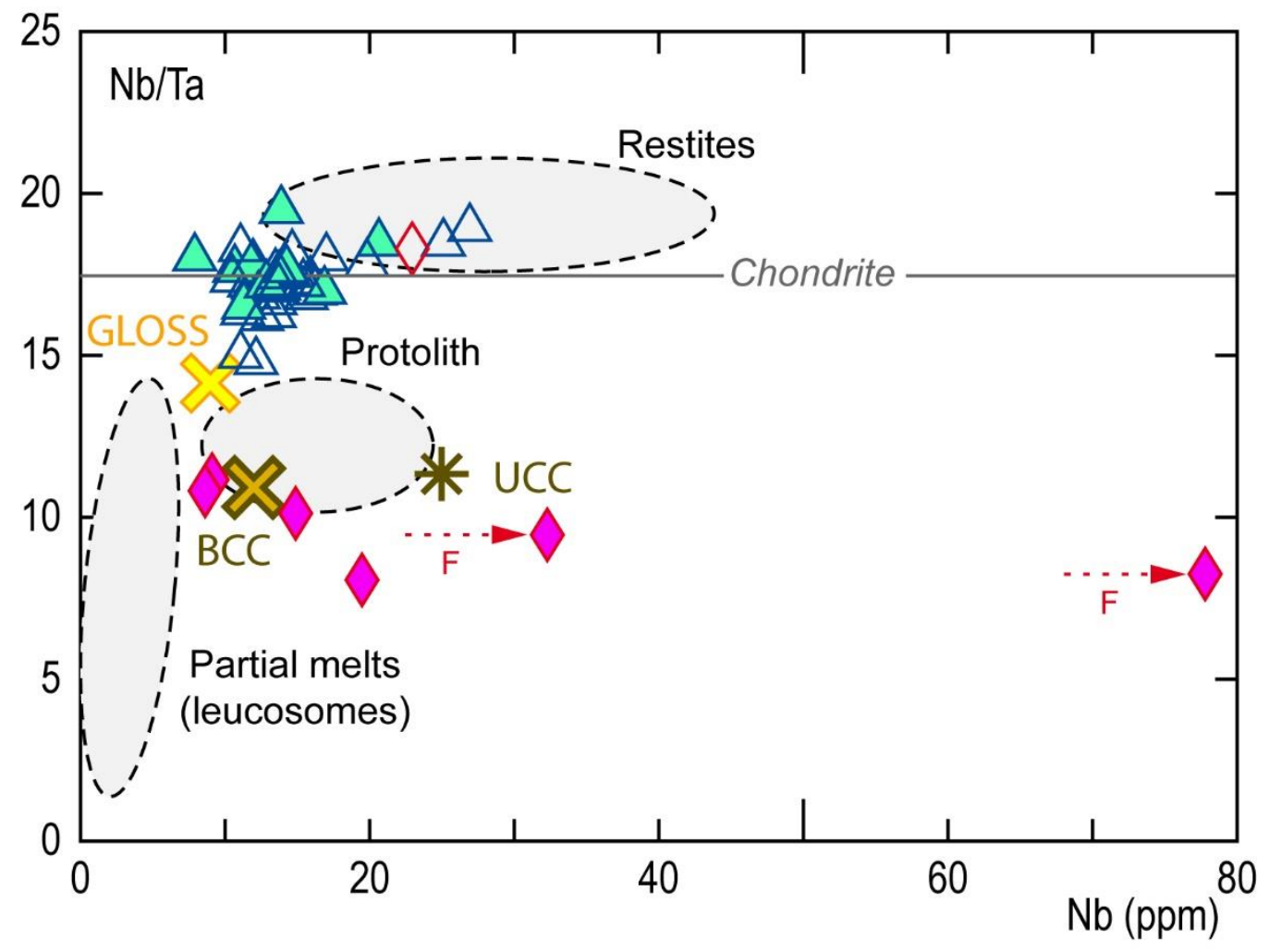

Caroff et al. Fig. 12

Figure 13. Cs, Be and Ga variation diagrams for W-Armorican kersantites, Q-micromonzonite and microgranodiorites (symbols as in Fig. 6). The font size of "cordierite" and the thickness of the corresponding dashed arrows are proportional to the expected relative content of Cs, $\mathrm{Be}$, and $\mathrm{Ga}$ in the melting cordierite: $\mathrm{Yb}<<\mathrm{Cs}<<\mathrm{Be}<\mathrm{Ga}$ ( $\mathrm{Yb}, \mathrm{Cs}$ and $\mathrm{Be}$ in cordierite: Bea et al., 1994; Ramesh Kumar et al., 1995; Evensen and London, 2003; Ga in cordierite: Langer, 1971; Ramesh Kumar et al., 1995). (a) Yb/Cs vs. Cs diagram. References for the other Variscan kersantites (K.) in Fig. 6. (b) Yb/Be vs. Be diagram. Inset: Pressure-temperature diagram for fluid-present conditions, showing the "in" and "out" curves for the main minerals during experimental melting of a cordierite-bearing gneiss (Koester et al., 2002). (c) Yb/Ga vs. Ga diagram. 

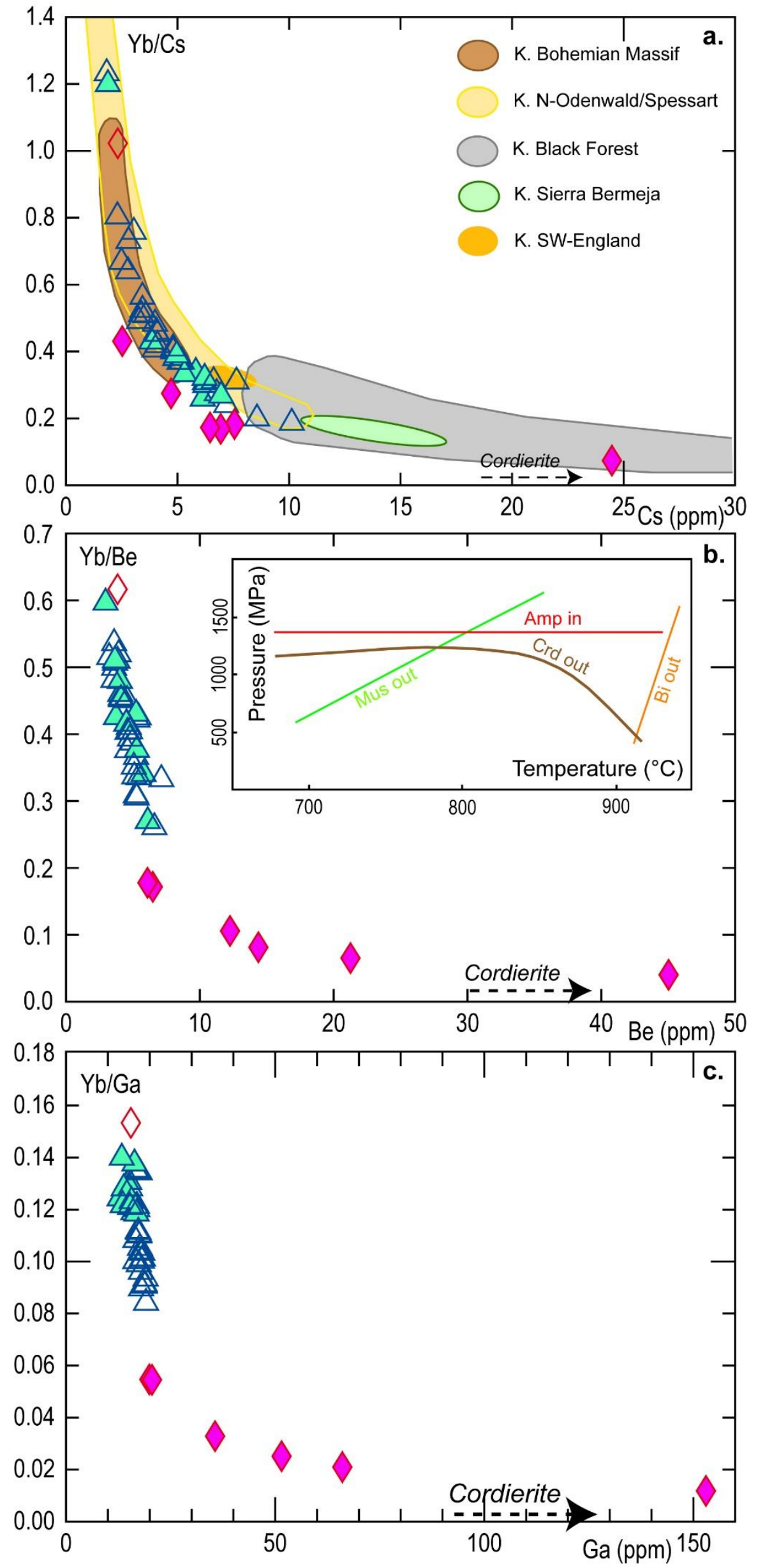

Caroff et al. Fig. 13 
Figure 14. Th-Hf-Nb/2 discrimination diagram (Krmíček et al., 2011) for Armorican precollisional dolerites and syn-collisional kersantites/ Q-micromonzonite/microgranodiorites (347-310 Ma), compared with syn-/post-collisional lamprophyres/lampyrites/lamproites from the Bohemian Massif (340-275 Ma; data from Krmíček et al., 2020). K-M: kersantites from the Bohemian Moldanubian Zone; K-MS: kersantite from the Bohemian Moravo-Silesian Zone; K-ST: kersantites from the Bohemian Saxo-Thuringian Zone.

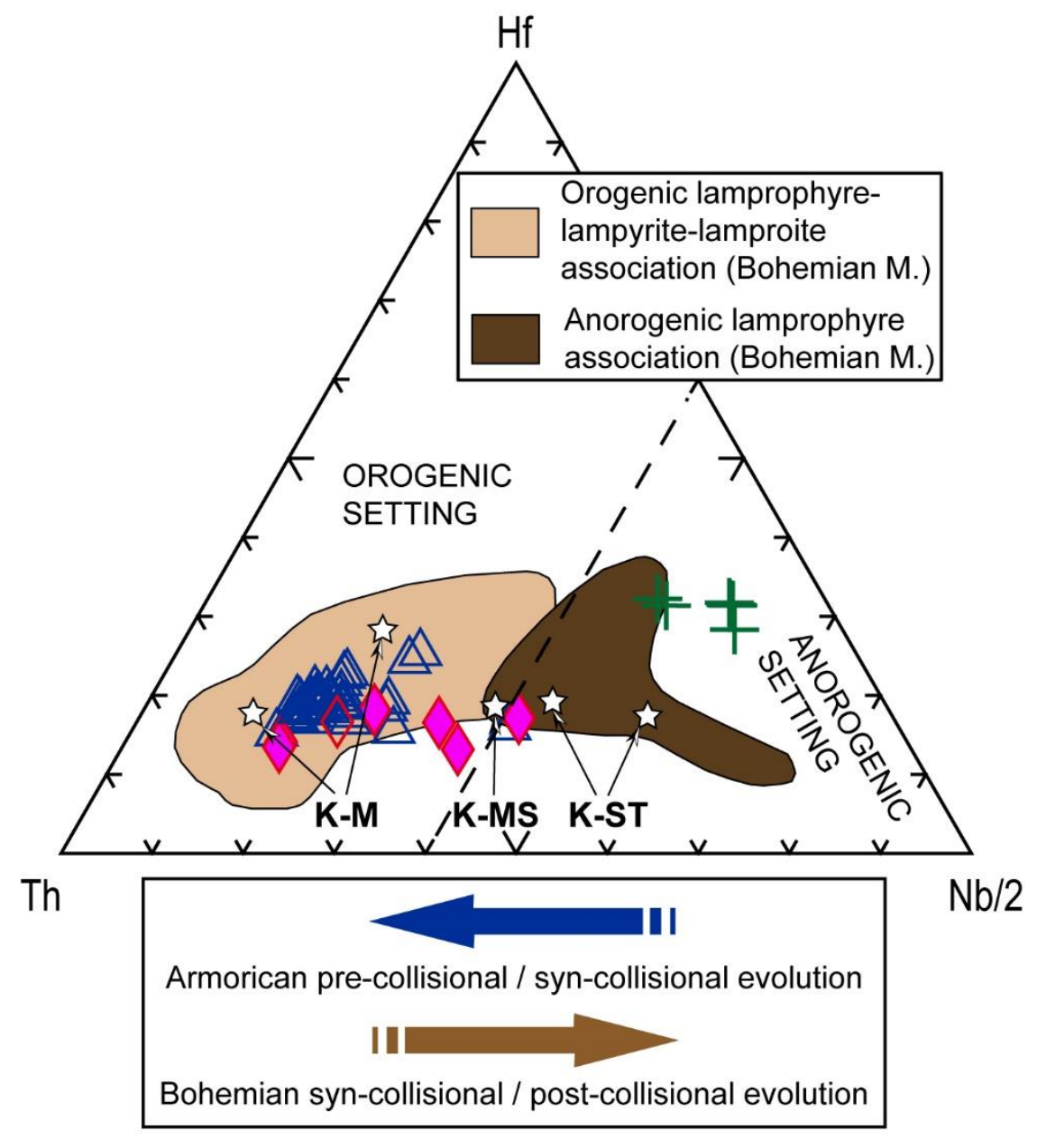

\section{Caroff et al. Fig. 14}

Figure 15. Sketches illustrating two different Variscan geodynamic models for the Armorica and Avalonia collided microplates near 340-330 Ma. The south suture model between Armorica and Gondwana is from Ballèvre et al. (2009). (a) Model A (slab roll back), adapted from Duretz et al. (2011) and Guillot and Replumaz (2013). (b) Model B (delamination), adapted from Ma et al. (2014) and Li et al. (2016). These two mechanisms may account for (i) 
the Saint-Jean-du-Doigt gabbro and A-type granites (Caroff et al., 2011; Barboni and Bussi, 2013), together with anorogenic basalts and dolerites (including the Brest Bay ones) emplaced in the northern part of the Armorican Massif (Lahaye et al., 1995; Caroff et al., 1996, 2016, 2020) (347-330 Ma), and (ii) the later W-Armorican kersantites and microgranodiorite (330$310 \mathrm{Ma})$.

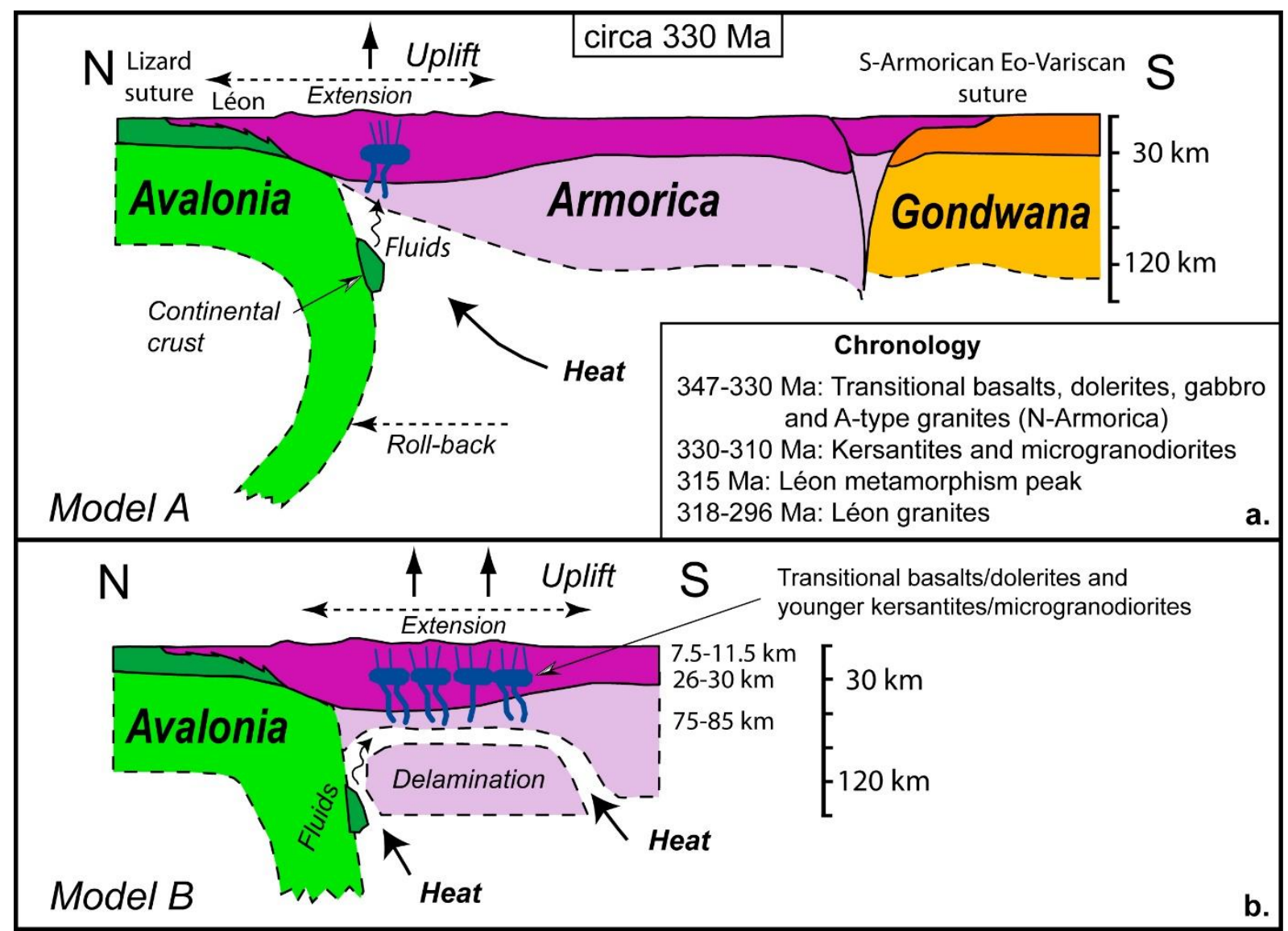

Caroff et al. Fig. 15

\section{Table captions}

Table 1. Chemical data (wt\% oxides, ppm elements) on selected whole rock samples.

Table 2. Isotopic data on selected whole rock samples.

\section{Supplementary data}


Analytical methods.

Table S1. Whole rock analyses (kersantites, Q-micromonzonite, microgranodiorites, micromonzogranites, and dolerites).

Table S2. Analyses of amphiboles in kersantites, cations normalized to $23 \mathrm{O}$ and $13 \mathrm{CNK}$ (total cations except $\mathrm{Ca}, \mathrm{Na}$ and $\mathrm{K}=13$ ).

Table S3. Analyses of clinopyroxenes in kersantites, cations normalized to 6 O.

Table S4. Analyses of dark micas in kersantites, cations normalized to $22 \mathrm{O}$.

Fig. S1. Photomicrographs of two samples from the W-Armorican kersantite/microgranodiorite hypabyssal network. 
Table 1. Chemical data (wt\% oxides, ppm elements) on selected whole rock samples.

\begin{tabular}{|c|c|c|c|c|c|c|c|c|c|c|c|c|c|}
\hline Type & K. & $\mathrm{K}$. & $\mathrm{K}$. & $\mathrm{K}$. & $\mathrm{K}$. & $\mathrm{K}$. & K. & $\mathrm{K}$. & $\mathrm{K}$. & K. & $\mathrm{Q}-\mu \mathrm{mz}$ & $\mu \mathrm{gd}$ & $\mu \mathrm{gd}$ \\
\hline Sample & RB-1a & RB-2 & RB-3 & RB-10b & RB-12a & RB-24b & RB-29 & RB-30 & RB-33 & RB-43 & RB-12b & RB-11 & RB-14b \\
\hline Location & L. & H.C. & H.C. & L.-D. & H.C. & P.-D. & P. & L.-D. & Hanvec & H.C. & H.C. & L.-D. & L.-D. \\
\hline Minerals & & & & Chl. & Chl. & Chl. & & & Cpx & Amp. & & & \\
\hline $\mathrm{SiO}_{2}$ & 46.10 & 45.60 & 51.10 & 53.30 & 51.30 & 50.80 & 47.20 & 50.60 & 51.10 & 46.20 & 61.76 & 77.90 & 73.90 \\
\hline $\mathrm{TiO}_{2}$ & 0.84 & 1.16 & 1.02 & 0.99 & 0.90 & 1.26 & 1.40 & 1.01 & 1.19 & 0.85 & 0.41 & 0.11 & 0.24 \\
\hline $\mathrm{Al}_{2} \mathrm{O}_{3}$ & 10.62 & 11.67 & 14.04 & 14.56 & 14.17 & 15.45 & 14.60 & 13.52 & 14.81 & 11.25 & 14.56 & 12.86 & 13.43 \\
\hline $\mathrm{Fe}_{2} \mathrm{O}_{3}{ }^{\text {tot }}$ & 7.73 & 8.26 & 7.15 & 6.92 & 7.19 & 8.04 & 8.27 & 7.33 & 8.45 & 8.97 & 3.75 & 1.42 & 2.11 \\
\hline $\mathrm{MnO}$ & 0.13 & 0.10 & 0.10 & 0.10 & 0.11 & 0.10 & 0.13 & 0.11 & 0.12 & 0.12 & 0.03 & 0.03 & 0.03 \\
\hline $\mathrm{MgO}$ & 12.62 & 12.00 & 7.89 & 7.07 & 7.24 & 7.36 & 8.48 & 8.88 & 9.06 & 15.06 & 1.18 & 0.23 & 0.39 \\
\hline $\mathrm{CaO}$ & 7.17 & 6.83 & 6.02 & 4.74 & 5.30 & 6.84 & 6.55 & 5.97 & 5.83 & 6.49 & 4.25 & 0.03 & 0.07 \\
\hline $\mathrm{Na}_{2} \mathrm{O}$ & 1.80 & 1.42 & 2.59 & 2.84 & 2.58 & 3.09 & 2.96 & 2.85 & 2.75 & 0.94 & 4.04 & 3.02 & 3.59 \\
\hline $\mathrm{K}_{2} \mathrm{O}$ & 2.08 & 1.13 & 1.79 & 3.10 & 2.64 & 1.01 & 2.20 & 1.91 & 0.86 & 1.84 & 4.88 & 2.33 & 2.32 \\
\hline $\mathrm{P}_{2} \mathrm{O}_{5}$ & 0.54 & 0.76 & 0.50 & 0.56 & 0.50 & 0.49 & 0.58 & 0.60 & 0.43 & 0.53 & 0.20 & 0.04 & 0.06 \\
\hline L.O.I. & 10.00 & 10.71 & 6.68 & 6.50 & 6.91 & 6.21 & 7.64 & 7.04 & 5.57 & 7.95 & 4.12 & 1.83 & 2.60 \\
\hline Total & 99.63 & 99.64 & 98.88 & 100.68 & 98.84 & 100.65 & 100.01 & 99.82 & 100.17 & 100.20 & 99.18 & 99.80 & 98.74 \\
\hline $\mathrm{Be}$ & 3.73 & 5.80 & 5.27 & 4.95 & 5.43 & 3.94 & 4.10 & 6.60 & 5.24 & 3.65 & 3.85 & 21.25 & 14.37 \\
\hline $\mathrm{Sc}$ & 21.50 & 24.01 & 19.75 & 19.03 & 18.98 & 20.34 & 21.34 & 20.79 & 25.26 & 24.37 & 11.67 & 1.57 & 2.86 \\
\hline V & 148 & 166 & 140 & 136 & 125 & 144 & 143 & 143 & 164 & 158 & 27.9 & 11.0 & 24.7 \\
\hline $\mathrm{Cr}$ & 872 & 614 & 489 & 362 & 397 & 278 & 369 & 570 & 392 & 879 & 6.4 & 28.2 & 20.5 \\
\hline $\mathrm{Co}$ & 43.90 & 43.20 & 31.90 & 25.55 & 25.01 & 34.28 & 36.12 & 33.40 & 32.90 & 49.44 & 9.32 & 8.94 & 2.17 \\
\hline $\mathrm{Ni}$ & 371 & 321 & 164 & 94.0 & 102 & 132 & 179 & 212 & 69.7 & 341 & 2.9 & 29.0 & 16.3 \\
\hline $\mathrm{Ga}$ & 12.78 & 15.09 & 17.95 & 17.17 & 18.14 & 17.04 & 15.33 & 17.39 & 16.36 & 13.31 & 15.50 & 66.05 & 35.63 \\
\hline $\mathrm{Rb}$ & 115.1 & 51.23 & 72.67 & 112.1 & 88.49 & 32.58 & 96.83 & 81.73 & 37.89 & 69.60 & 147.9 & 265.9 & 140.7 \\
\hline $\mathrm{Sr}$ & 699 & 518 & 989 & 585 & 606 & 951 & 992 & 914 & 439 & 652 & 517 & 74.7 & 140.7 \\
\hline Y & 17.51 & 24.83 & 18.34 & 23.45 & 22.64 & 24.61 & 23.14 & 21.27 & 26.01 & 21.99 & 30.24 & 16.71 & 12.33 \\
\hline $\mathrm{Zr}$ & 165 & 322 & 241 & 253 & 222 & 237 & 276 & 278 & 232 & 205 & 277 & 244 & 171 \\
\hline $\mathrm{Nb}$ & 10.69 & 20.65 & 13.40 & 13.72 & 14.65 & 16.23 & 19.82 & 15.41 & 11.30 & 12.87 & 22.96 & 32.30 & 14.89 \\
\hline $\mathrm{Cs}$ & 6.13 & 5.82 & 3.97 & 5.20 & 3.58 & 2.80 & 4.09 & 4.11 & 1.88 & 6.96 & 2.32 & 7.56 & 6.94 \\
\hline $\mathrm{Ba}$ & 1427 & 1589 & 1322 & 1476 & 1245 & 850 & 1932 & 1727 & 1227 & 1613 & 2237 & 473 & 339 \\
\hline $\mathrm{La}$ & 42.93 & 63.21 & 44.82 & 67.23 & 64.29 & 99.72 & 57.64 & 48.22 & 36.42 & 52.03 & 72.26 & 54.61 & 37.61 \\
\hline $\mathrm{Ce}$ & 86.00 & 136.8 & 93.03 & 133.8 & 129.1 & 183.1 & 121.5 & 99.25 & 78.13 & 101.3 & 142.85 & 73.79 & 51.42 \\
\hline
\end{tabular}




\begin{tabular}{|c|c|c|c|c|c|c|c|c|c|c|c|c|c|}
\hline $\operatorname{Pr}$ & 9.90 & 16.83 & 11.01 & 15.42 & 14.80 & 18.92 & 14.95 & 12.21 & 10.32 & 11.89 & 17.01 & 11.02 & 8.21 \\
\hline $\mathrm{Nd}$ & 37.90 & 66.97 & 42.78 & 58.38 & 55.75 & 65.06 & 59.30 & 47.99 & 43.21 & 45.03 & 64.31 & 38.52 & 29.38 \\
\hline $\mathrm{Sm}$ & 6.44 & 11.41 & 7.58 & 9.50 & 9.14 & 8.86 & 9.56 & 8.63 & 7.76 & 7.72 & 11.32 & 6.73 & 5.14 \\
\hline $\mathrm{Eu}$ & 1.50 & 2.29 & 1.64 & 1.97 & 1.80 & 2.18 & 2.04 & 1.81 & 1.75 & 1.65 & 2.19 & 1.08 & 0.857 \\
\hline $\mathrm{Gd}$ & 4.92 & 7.67 & 5.47 & 6.59 & 6.32 & 6.63 & 6.64 & 6.17 & 5.79 & 5.87 & 7.84 & 4.84 & 3.57 \\
\hline $\mathrm{Tb}$ & 0.632 & 0.923 & 0.690 & 0.823 & 0.792 & 0.822 & 0.807 & 0.753 & 0.792 & 0.747 & 1.06 & 0.628 & 0.461 \\
\hline Dy & 3.40 & 4.71 & 3.63 & 4.30 & 4.09 & 4.37 & 4.27 & 3.93 & 4.49 & 4.04 & 5.61 & 3.17 & 2.39 \\
\hline Ho & 0.653 & 0.863 & 0.679 & 0.818 & 0.773 & 0.846 & 0.801 & 0.726 & 0.882 & 0.765 & 0.735 & 0.570 & 0.447 \\
\hline $\mathrm{Er}$ & 1.78 & 2.24 & 1.82 & 2.18 & 2.04 & 2.30 & 2.13 & 1.94 & 2.45 & 2.05 & 2.00 & 1.49 & 1.22 \\
\hline $\mathrm{Yb}$ & 1.586 & 1.970 & 1.607 & 1.917 & 1.819 & 2.05 & 1.852 & 1.720 & 2.252 & 1.861 & 2.38 & 1.385 & 1.170 \\
\hline $\mathrm{Lu}$ & 0.226 & 0.275 & 0.227 & 0.275 & 0.256 & 0.293 & 0.263 & 0.242 & 0.321 & 0.265 & 0.326 & 0.189 & 0.160 \\
\hline Hf & 5.04 & 10.05 & 7.32 & 6.90 & 6.48 & 5.58 & 7.03 & 7.67 & 6.15 & 5.78 & 8.68 & 8.02 & 5.32 \\
\hline $\mathrm{Ta}$ & 0.606 & 1.12 & 0.824 & 0.787 & 0.809 & 0.958 & 1.11 & 0.896 & 0.684 & 0.750 & 1.26 & 3.42 & 1.47 \\
\hline $\mathrm{Pb}$ & 45.36 & 11.11 & 18.23 & 10.22 & 14.95 & 13.08 & 15.60 & 13.62 & 13.59 & 19.79 & 8.24 & 83.44 & 23.95 \\
\hline Th & 22.83 & 36.02 & 21.47 & 26.68 & 24.84 & 16.83 & 25.34 & 23.94 & 21.43 & 17.87 & 31.97 & 24.38 & 16.57 \\
\hline $\mathrm{U}$ & 5.85 & 7.61 & 5.07 & 5.71 & 5.04 & 3.16 & 4.08 & 6.11 & 3.90 & 4.46 & 6.75 & 14.39 & 6.92 \\
\hline
\end{tabular}

K.: kersantite; Q- $\mu m z:$ quartz-micromonzonite; $\mu \mathrm{gd}$ : microgranodiorite; L.: Loperhet (RB-1a: Kersanton); H.C.: Hôpital Camfrout (RB-2: Kerdréolet; RB-3: Kerascoët); L.-D.: Logonna-Daoulas (RB-11: Le Roz); P.-D.: Plougastel-Daoulas (RB-24b: Illien ar Gwen); P.:

Poullaouenn, Châteaulin Basin (RB-29 is located in Fig. 2b); Chl.: systematic chloritization of the dark micas (biotite/phlogopite), making the rocks much lighter; Cpx: presence of fresh euhedral clinopyroxene phenocrysts, sometimes as glomerocrysts in RB-33; Amp: presence of fresh amphibole, as microcrysts in RB-43; L.O.I.: Loss on ignition. Complete data set in Supplementary Table S1. 
Table 2. Isotopic data on selected whole rock samples.

\begin{tabular}{|c|c|c|c|c|c|c|c|c|c|c|c|c|c|c|}
\hline Sample & City & Hamlet & $\begin{array}{l}\mathrm{Rb} \\
\mathrm{ppm}\end{array}$ & $\begin{array}{l}\mathrm{Sr} \\
\mathrm{ppm}\end{array}$ & ${ }^{87} \mathrm{Rb} /{ }^{86} \mathrm{Sr}$ & ${ }^{87} \mathrm{Sr} /{ }^{86} \mathrm{Sr}$ & $\begin{array}{l} \pm 2 \sigma \mathrm{m} \\
\left(\mathrm{x} 10^{-6}\right)\end{array}$ & ${ }^{87} \mathrm{Sr} /{ }^{86} \mathrm{Sr}_{\mathrm{i}}$ & $\begin{array}{l}\text { Sm } \\
\text { ppm }\end{array}$ & $\begin{array}{l}\mathrm{Nd} \\
\mathrm{ppm}\end{array}$ & ${ }^{147} \mathrm{Sm} /{ }^{144} \mathrm{Nd}$ & ${ }^{143} \mathrm{Nd} /{ }^{144} \mathrm{Nd}$ & $\begin{array}{l} \pm 2 \sigma \mathrm{m} \\
\left(\mathrm{x} 10^{-6}\right)\end{array}$ & $\varepsilon_{\mathrm{Nd}}$ \\
\hline \multicolumn{15}{|c|}{ Kersantites } \\
\hline $\mathrm{RB}-1 \mathrm{a}$ & Loperhet & Kersanton & 115.1 & 699 & 0.477 & 0.709889 & 3 & 0.707718 & 6.44 & 37.90 & 0.103 & 0.512339 & 3 & -1.99 \\
\hline $\mathrm{RB}-2$ & L'Hôpital Ct & Kerdréolet & 51.23 & 518 & 0.286 & 0.708745 & 3 & 0.707441 & 11.41 & 66.97 & 0.103 & 0.512335 & 2 & -2.08 \\
\hline RB-3 & L’Hôpital Ct & Kerascoët & 72.67 & 989 & 0.213 & 0.709092 & 3 & 0.708124 & 7.58 & 42.78 & 0.107 & 0.512315 & 3 & -2.64 \\
\hline RB-10b & Logonna-D. & Pte Château & 112.1 & 585 & 0.554 & 0.709862 & 2 & 0.707337 & 9.50 & 58.38 & 0.098 & 0.512297 & 3 & -2.63 \\
\hline $\mathrm{RB}-12 \mathrm{a}$ & L'Hôpital Ct & RhunVras & 88.49 & 606 & 0.423 & 0.709425 & 3 & 0.707499 & 9.14 & 55.75 & 0.099 & 0.512306 & 4 & -2.49 \\
\hline $\mathrm{RB}-24 \mathrm{~b}$ & Plougastel-D. & Illien ar Gwen & 32.58 & 951 & 0.099 & 0.706205 & 2 & 0.705754 & 8.86 & 65.06 & 0.082 & 0.512376 & 3 & -0.44 \\
\hline RB-29 & Poullaouenn & Lasalle & 96.83 & 992 & 0.282 & 0.708372 & 3 & 0.707086 & 9.56 & 59.30 & 0.097 & 0.512324 & 2 & -2.07 \\
\hline $\mathrm{RB}-30$ & Logonna-D. & Rosmorduc & 81.73 & 914 & 0.259 & 0.709611 & 3 & 0.708433 & 8.63 & 47.99 & 0.109 & 0.512293 & 3 & -3.14 \\
\hline $\mathrm{RB}-33$ & Hanvec & Keromen & 37.89 & 439 & 0.250 & 0.709200 & 3 & 0.708063 & 7.76 & 43.21 & 0.109 & 0.512314 & 2 & -2.72 \\
\hline $\mathrm{RB}-43$ & L'Hôpital Ct & Kerbiaouen & 69.60 & 652 & 0.309 & 0.708453 & 3 & 0.707047 & 7.72 & 45.03 & 0.104 & 0.512342 & 5 & -1.97 \\
\hline \multicolumn{15}{|c|}{$Q$-micromonzonite } \\
\hline $\mathrm{RB}-12 \mathrm{~b}$ & L’Hôpital Ct & RhunVras & 147.9 & 517 & 0.828 & 0.711031 & 4 & 0.707259 & 11.32 & 64.31 & 0.106 & 0.512324 & 3 & -2.44 \\
\hline \multicolumn{15}{|c|}{ Microgranodiorites/Micromonzogranites } \\
\hline RB-11 & Logonna-D. & Le Roz & 265.9 & 74.7 & - & - & - & - & 6.73 & 38.52 & 0.106 & 0.512321 & 3 & -2.46 \\
\hline $\mathrm{RB}-14 \mathrm{~b}$ & Logonna-D. & Moulin Mer & 140.7 & 140.7 & - & - & - & - & 5.14 & 29.38 & 0.106 & 0.512312 & 2 & -2.65 \\
\hline LC-IL-1 & Crozon & Île Longue & 143.5 & 365.6 & 1.136 & 0.712415 & 6 & 0.707242 & 4.47 & 25.50 & 0.106 & 0.512338 & 4 & -2.10 \\
\hline
\end{tabular}

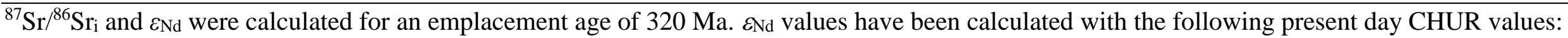

${ }^{143} \mathrm{Nd} /{ }^{144} \mathrm{Nd}=0.512638$ and ${ }^{147} \mathrm{Sm} /{ }^{144} \mathrm{Nd}=0.1967$. Error on the ${ }^{87} \mathrm{Rb} /{ }^{86} \mathrm{Sr}$ and ${ }^{147} \mathrm{Sm} /{ }^{144} \mathrm{Nd}$ ratios are $2 \%$ and $1 \%$ respectively. Complete data set in Supplementary

Table S1. 